\title{
Iron(III)-mediated Oxy-sulfonylation of enamides with sodium and lithium sulfinates
}

Philipp Kramer ${ }^{[a]}$, Miro Hałaczkiewicz, Yu Sun, Harald Kelm and Georg Manolikakes ${ }^{[a] *}$

[a] Department of Organic Chemistry,

Technical University Kaiserslautern

Erwin-Schrödinger-Str. Geb. 54,

67663 Kaiserslautern, Germany

E-mail: manolikakes@chemie.uni-kl.de

https://www.chemie.uni-kl.de/manolikakes

\section{Supporting Information}

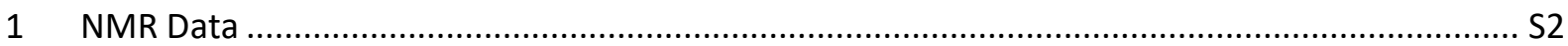

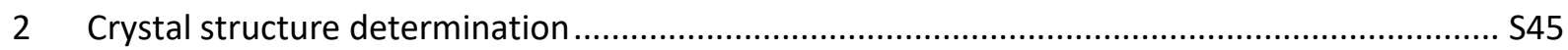




\section{NMR Data}

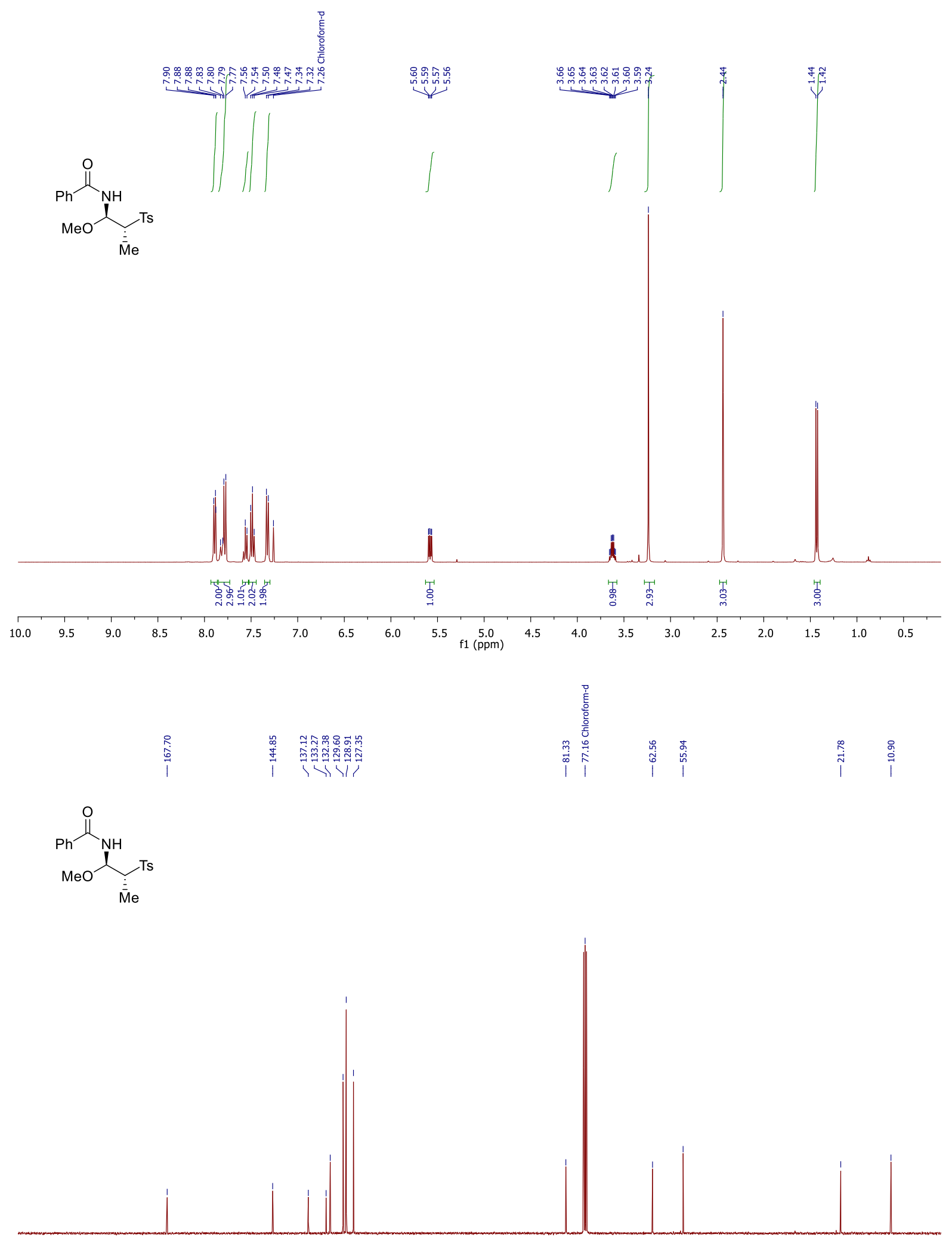

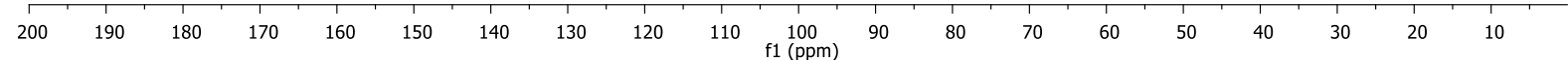

Figure $\mathrm{S1}{ }^{1} \mathrm{H}(400 \mathrm{MHz})$ and ${ }^{13} \mathrm{C}\left\{{ }^{1} \mathrm{H}\right\}(101 \mathrm{MHz}) \mathrm{NMR}$ spectra of $4 a$ in $\mathrm{CDCl}_{3}$. 

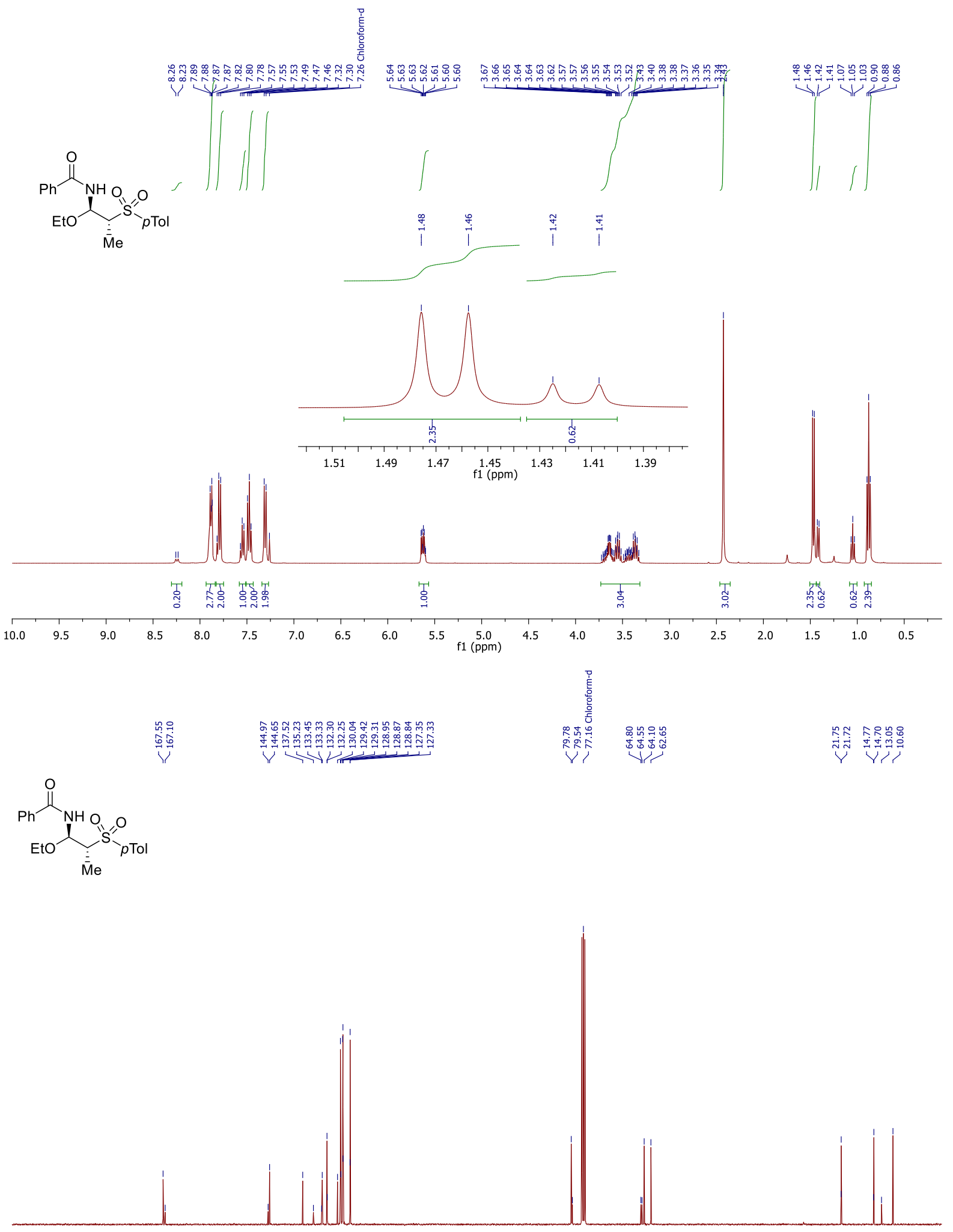

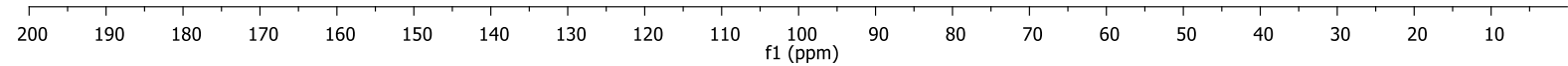

Figure S2: ${ }^{1} \mathrm{H}(400 \mathrm{MHz})$ and ${ }^{13} \mathrm{C}\left\{{ }^{1} \mathrm{H}\right\}(101 \mathrm{MHz}) \mathrm{NMR}$ spectra of $4 \boldsymbol{b}$ in $\mathrm{CDCl}$. 

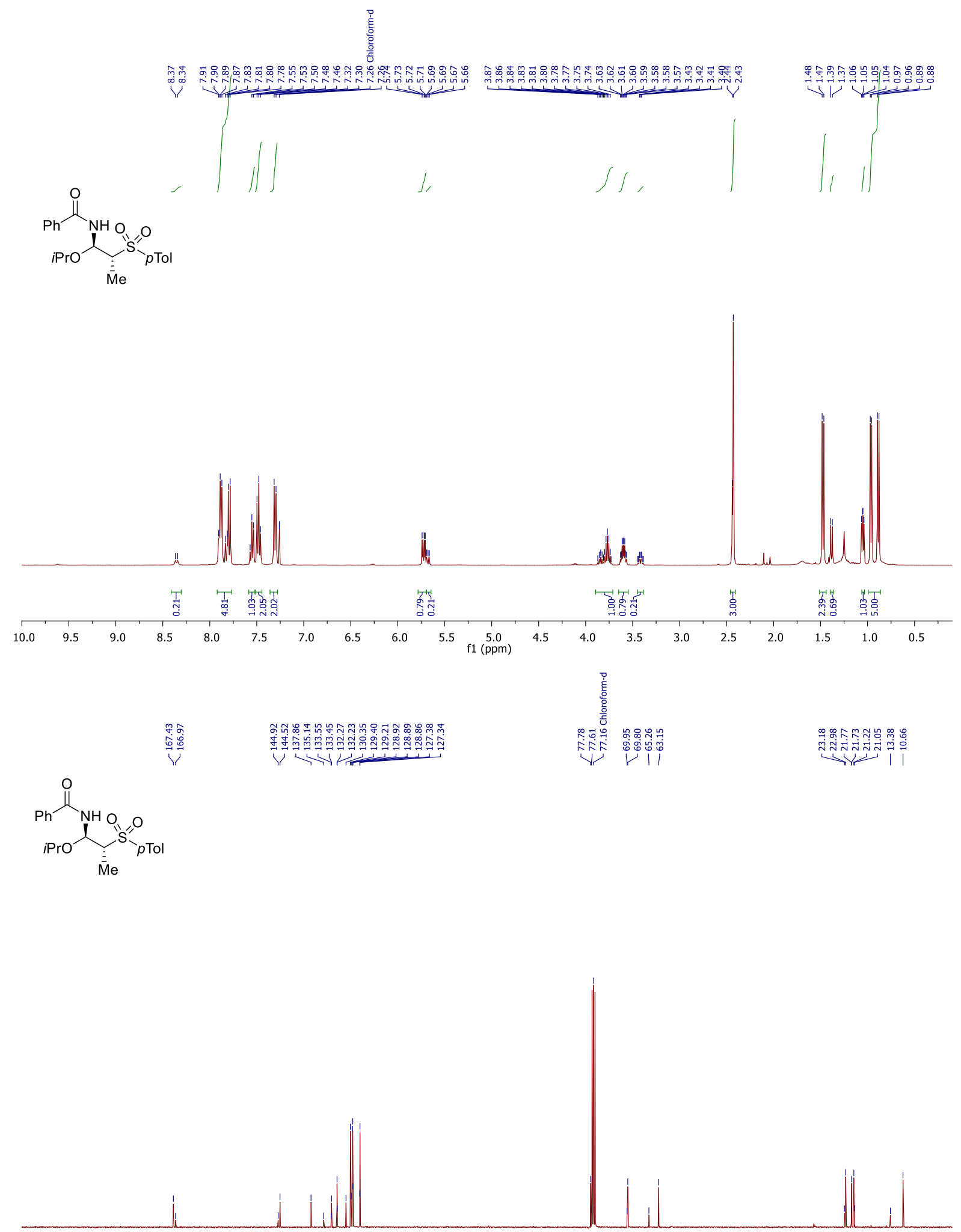

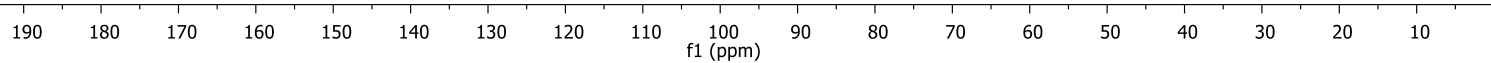

Figure S3: ${ }^{1} \mathrm{H}(400 \mathrm{MHz})$ and ${ }^{13} \mathrm{C}\left\{{ }^{1} \mathrm{H}\right\}(101 \mathrm{MHz}) \mathrm{NMR}$ spectra of $4 \mathrm{c}$ in $\mathrm{CDCl} 3$. 

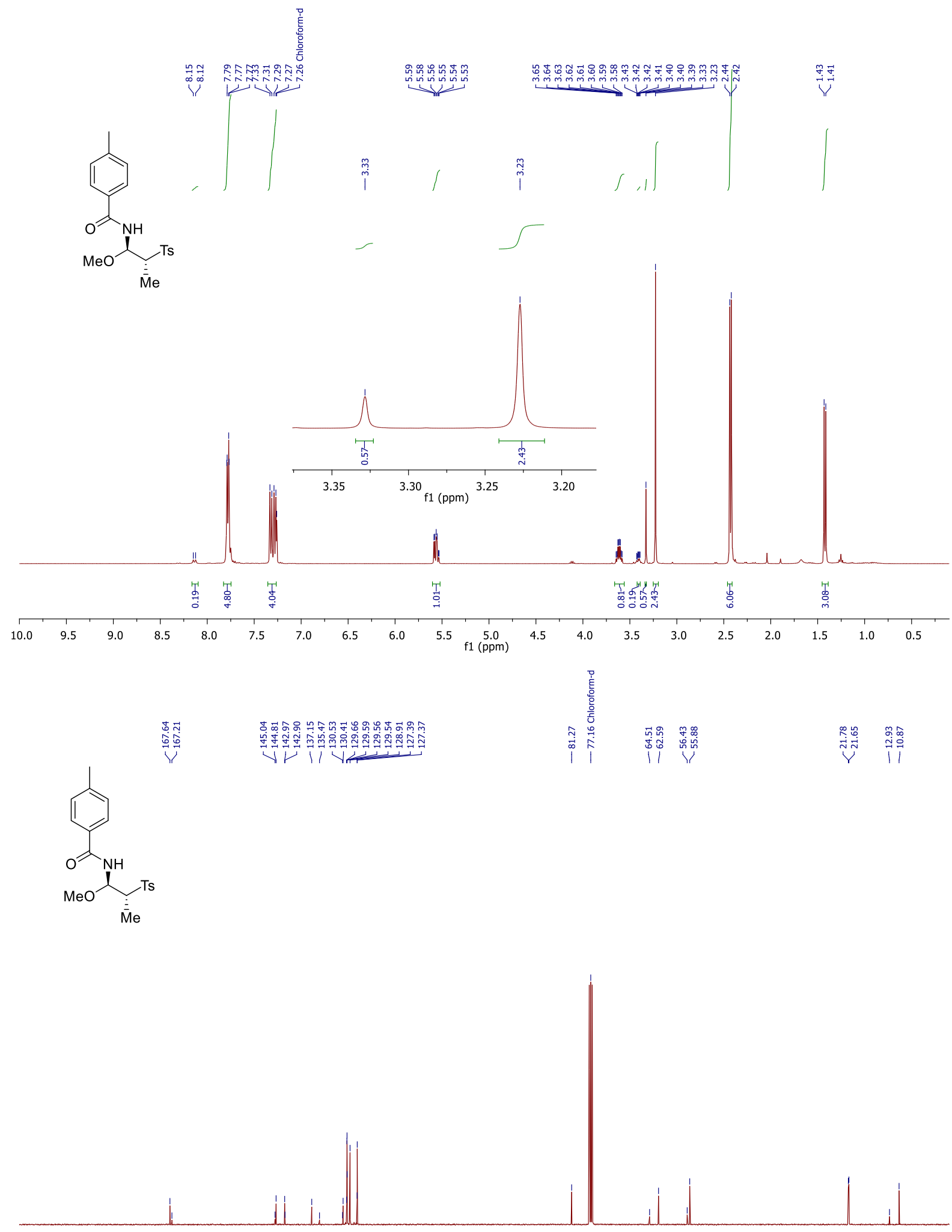

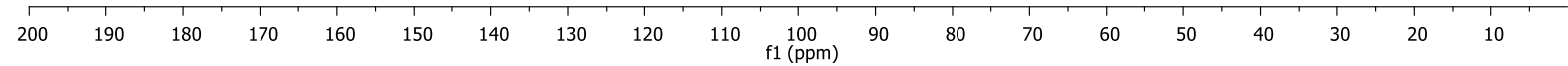

Figure $\mathrm{S}^{1} \mathrm{H}(400 \mathrm{MHz})$ and $\left.{ }^{13} \mathrm{C}^{1} \mathrm{H}\right\}(101 \mathrm{MHz}) \mathrm{NMR}$ spectra of $4 \mathrm{f}$ in $\mathrm{CDCl}$. 

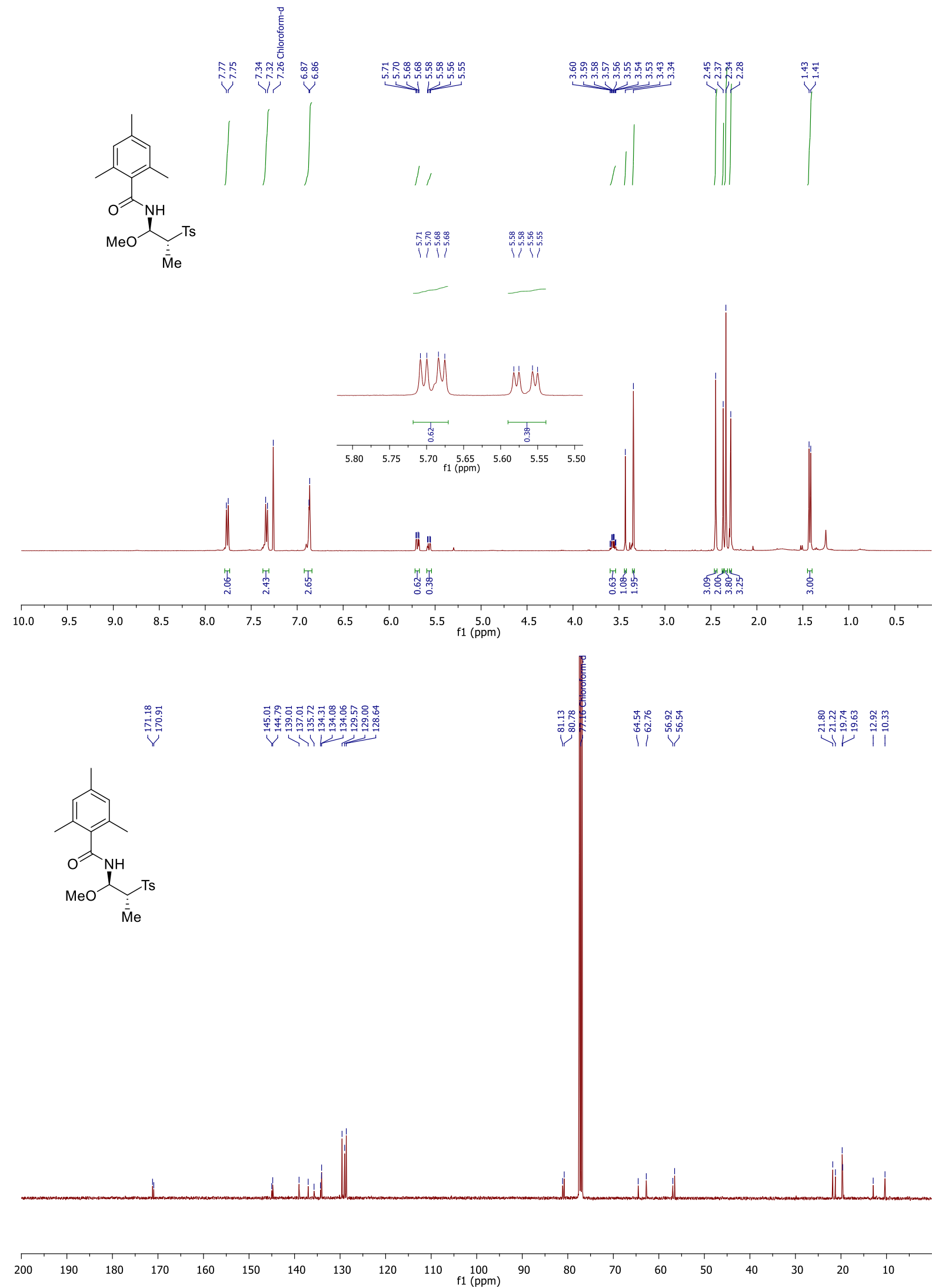

Figure $55:{ }^{1} \mathrm{H}(400 \mathrm{MHz})$ and ${ }^{13} \mathrm{C}\left\{{ }^{1} \mathrm{H}\right\}(101 \mathrm{MHz}) \mathrm{NMR}$ spectra of $\mathbf{4 g}$ in $\mathrm{CDCl}$. 

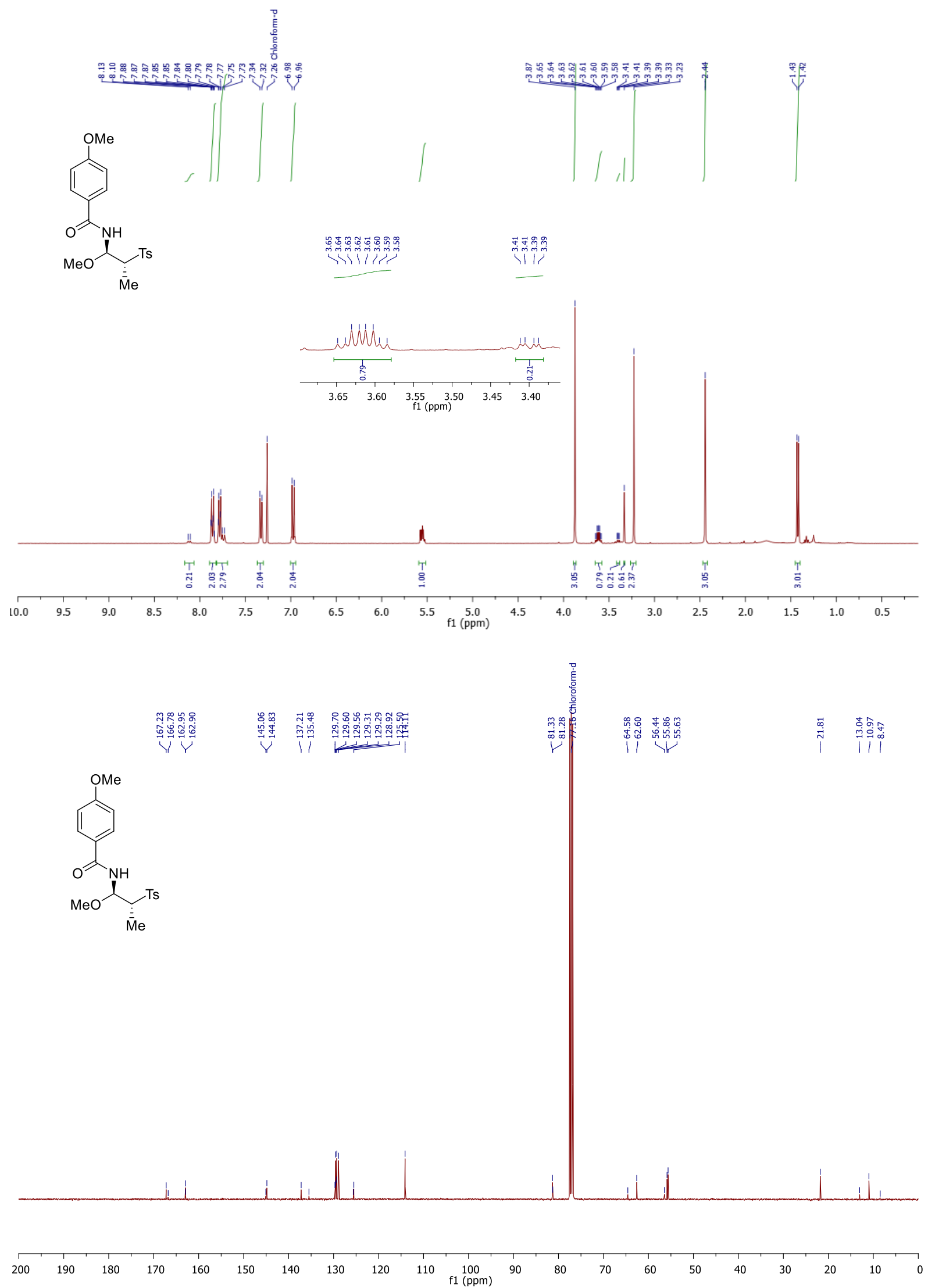

Figure S6: ${ }^{1} \mathrm{H}(400 \mathrm{MHz})$ and ${ }^{13} \mathrm{C}\left\{{ }^{1} \mathrm{H}\right\}(101 \mathrm{MHz})$ NMR spectra of $4 \boldsymbol{h}$ in $\mathrm{CDCl}$. 

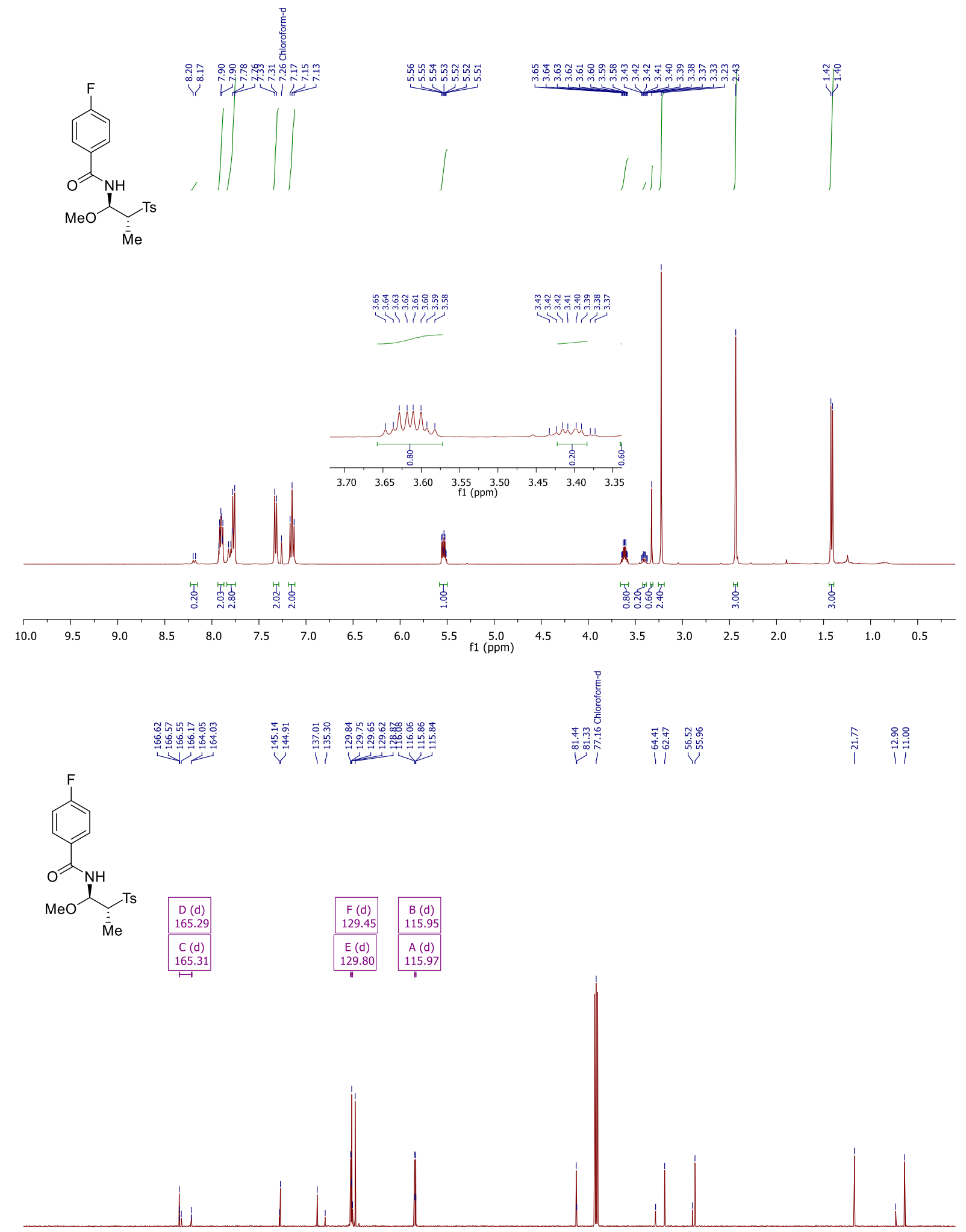

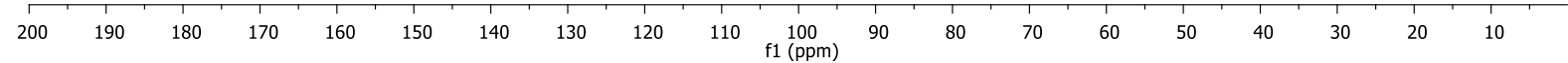



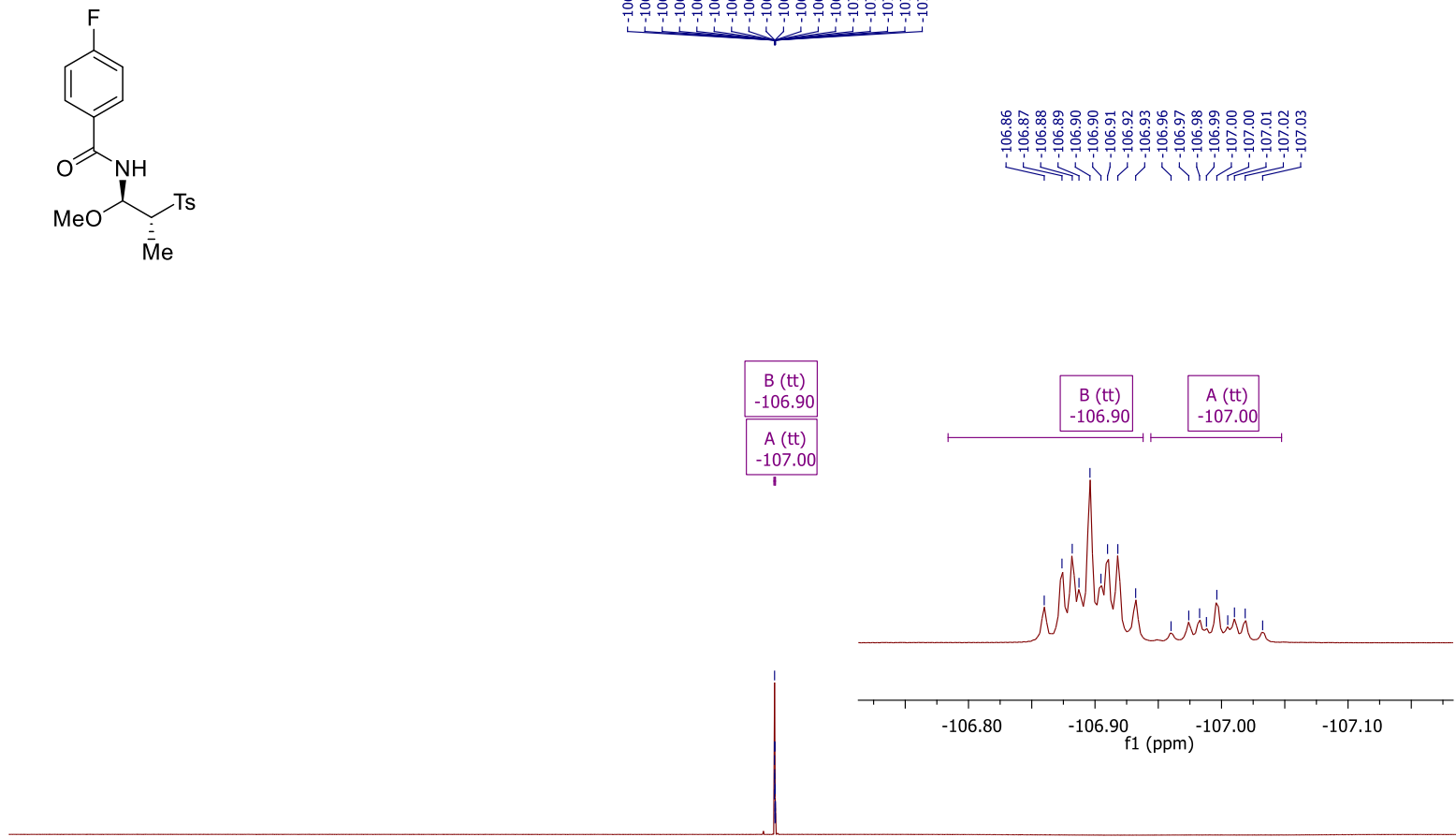

Figure S7: ${ }^{1} \mathrm{H}(400 \mathrm{MHz}),{ }^{13} \mathrm{C}\left\{{ }^{1} \mathrm{H}\right\}(101 \mathrm{MHz})$ and $\left.{ }^{19} \mathrm{~F}^{1}{ }^{1} \mathrm{H}\right\}(376 \mathrm{MHz}) \mathrm{NMR}$ spectra of $4 \mathrm{i}$ in $\mathrm{CDCl}$.<smiles>COC(NC(=O)c1ccc(C(F)(F)F)cc1)C(C)(C)C</smiles>

$\mathbf{x x}$
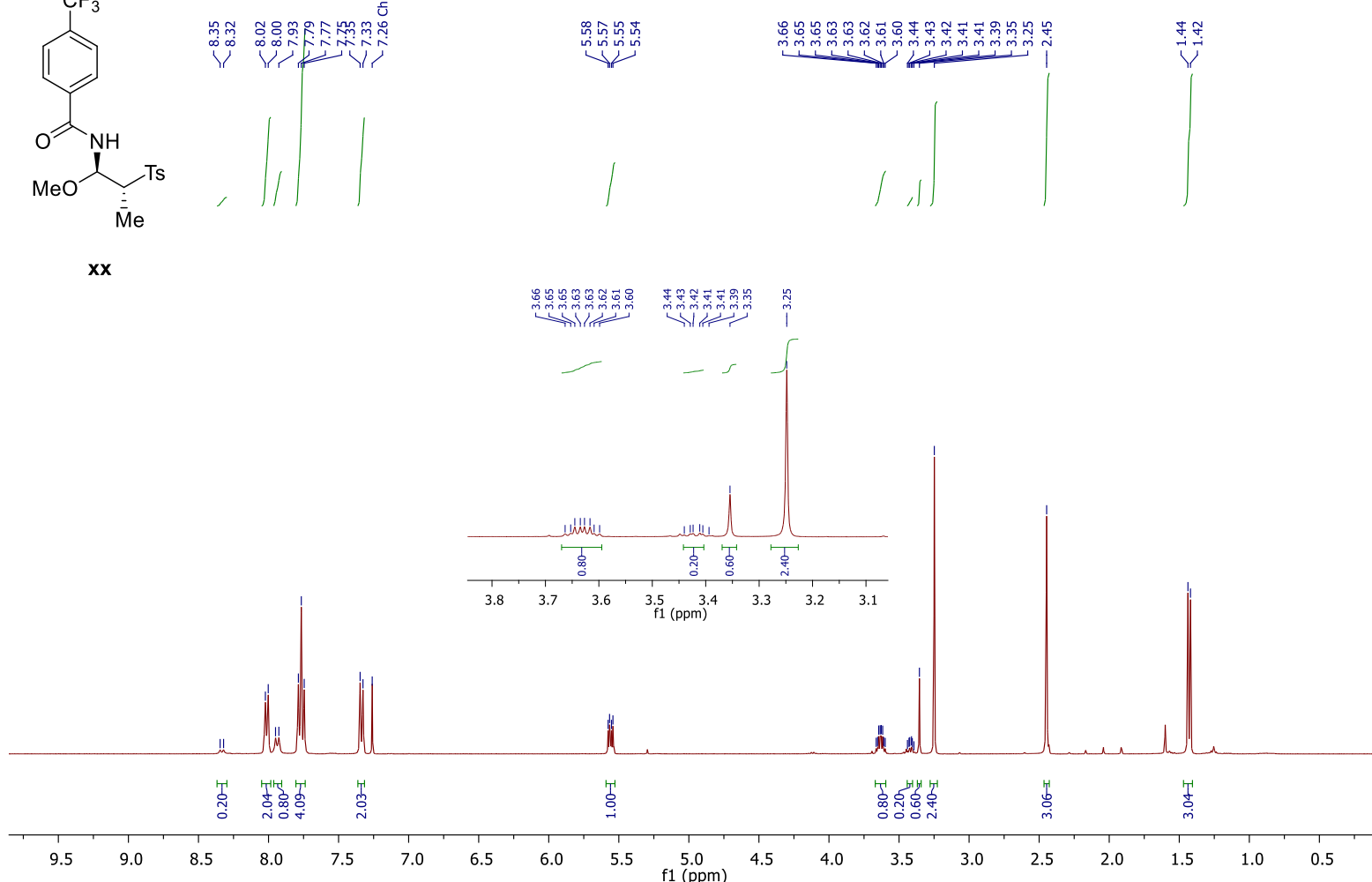


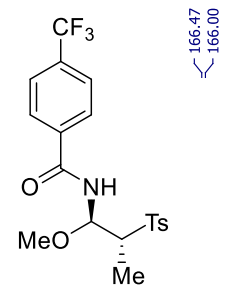

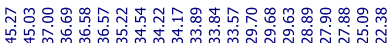

当

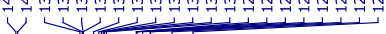

$\mathbf{x x}$

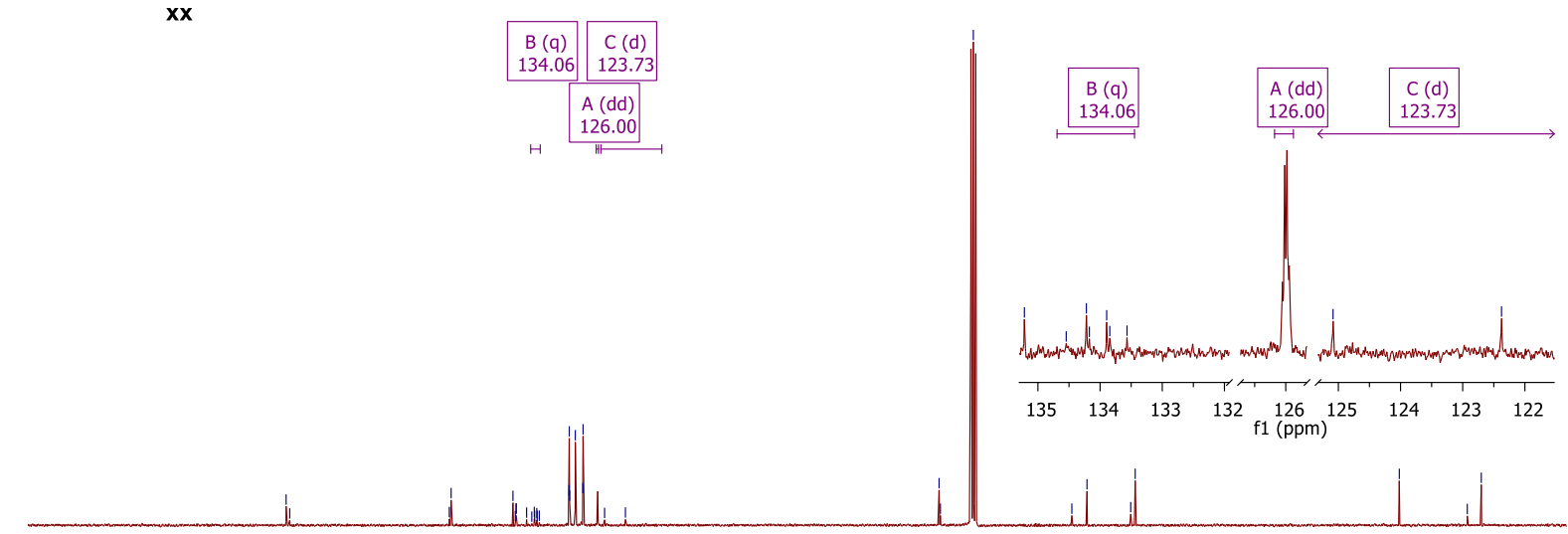

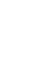

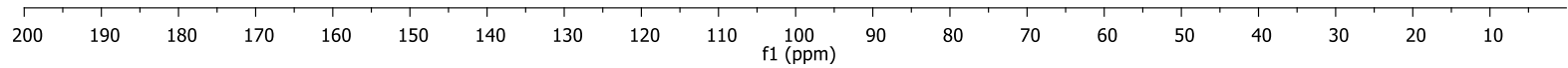

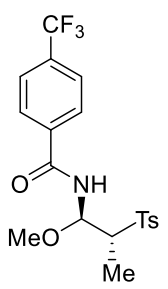

$\mathbf{x x}$
产

สุ

贷

i 

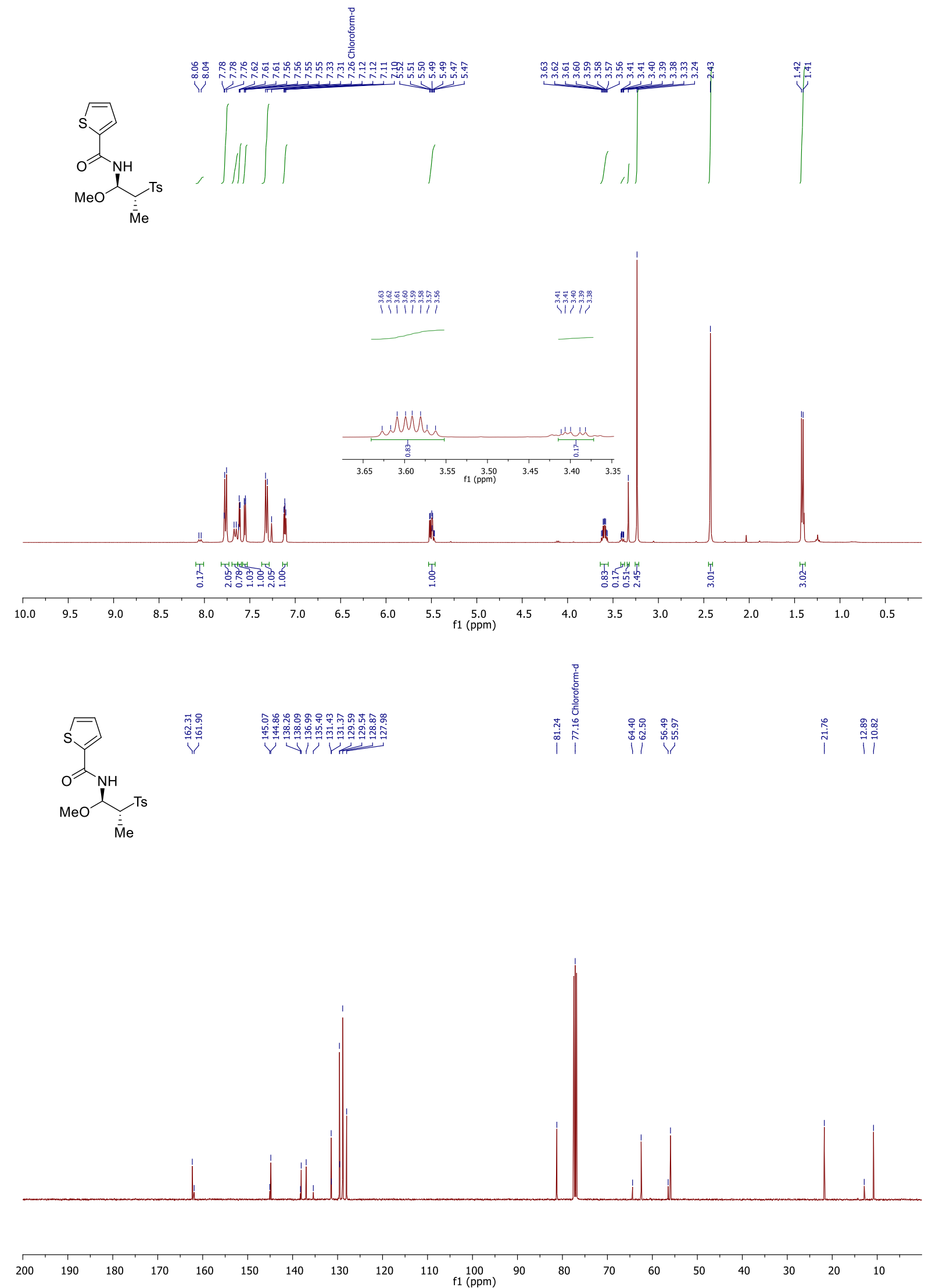

Figure S9: ${ }^{1 \mathrm{H}}(400 \mathrm{MHz})$ and ${ }^{13} \mathrm{C}\left\{{ }^{1} \mathrm{H}\right\}(101 \mathrm{MHz}) \mathrm{NMR}$ spectra of $4 \mathbf{k}$ in $\mathrm{CDCl} 3$. 

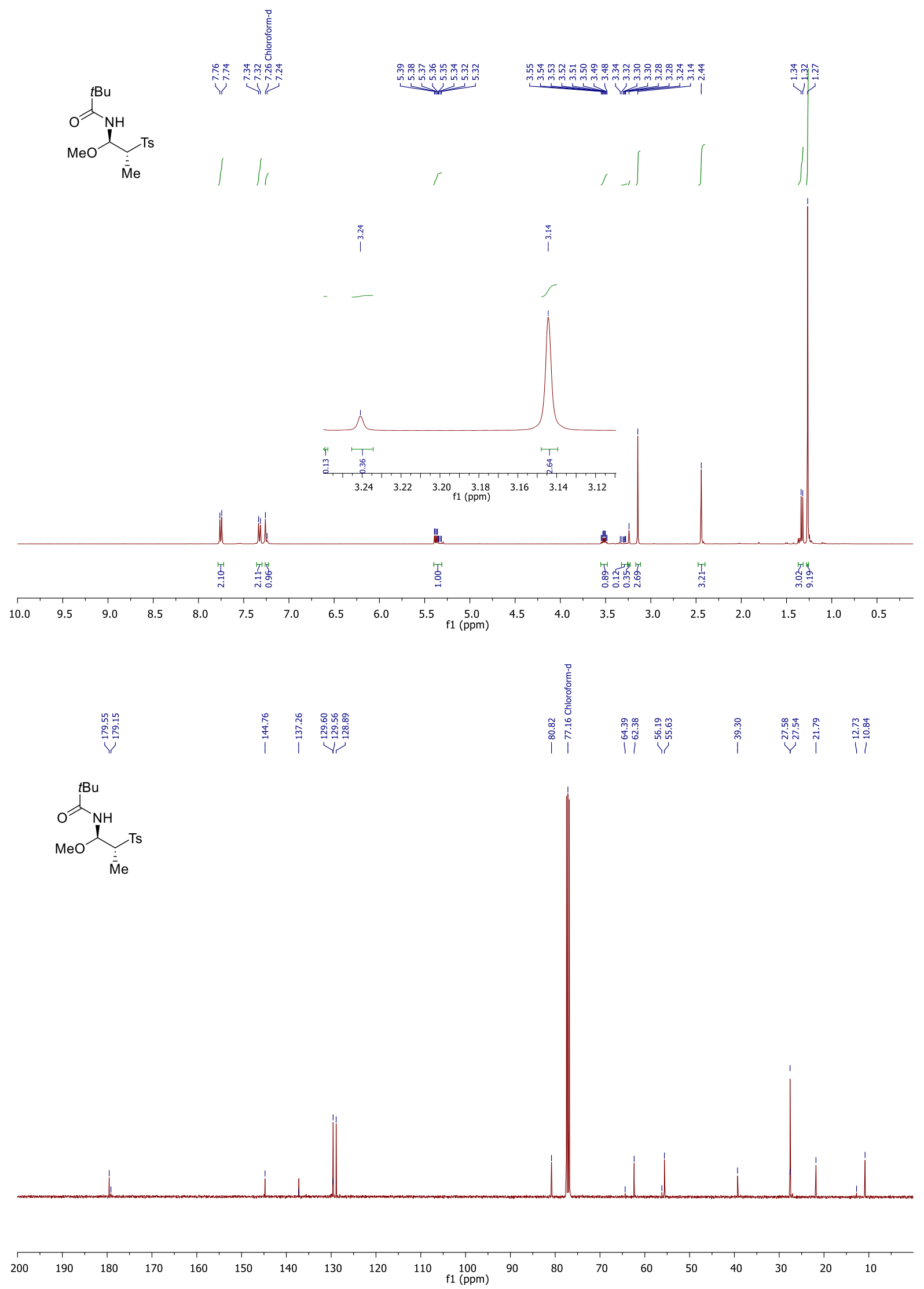

Figure S10: ${ }^{1} \mathrm{H}(400 \mathrm{MHz})$ and ${ }^{13} \mathrm{C}\left\{{ }^{1} \mathrm{H}\right\}(101 \mathrm{MHz}) \mathrm{NMR}$ spectra of $4 \mathrm{l}$ in $\mathrm{CDCl}$. 

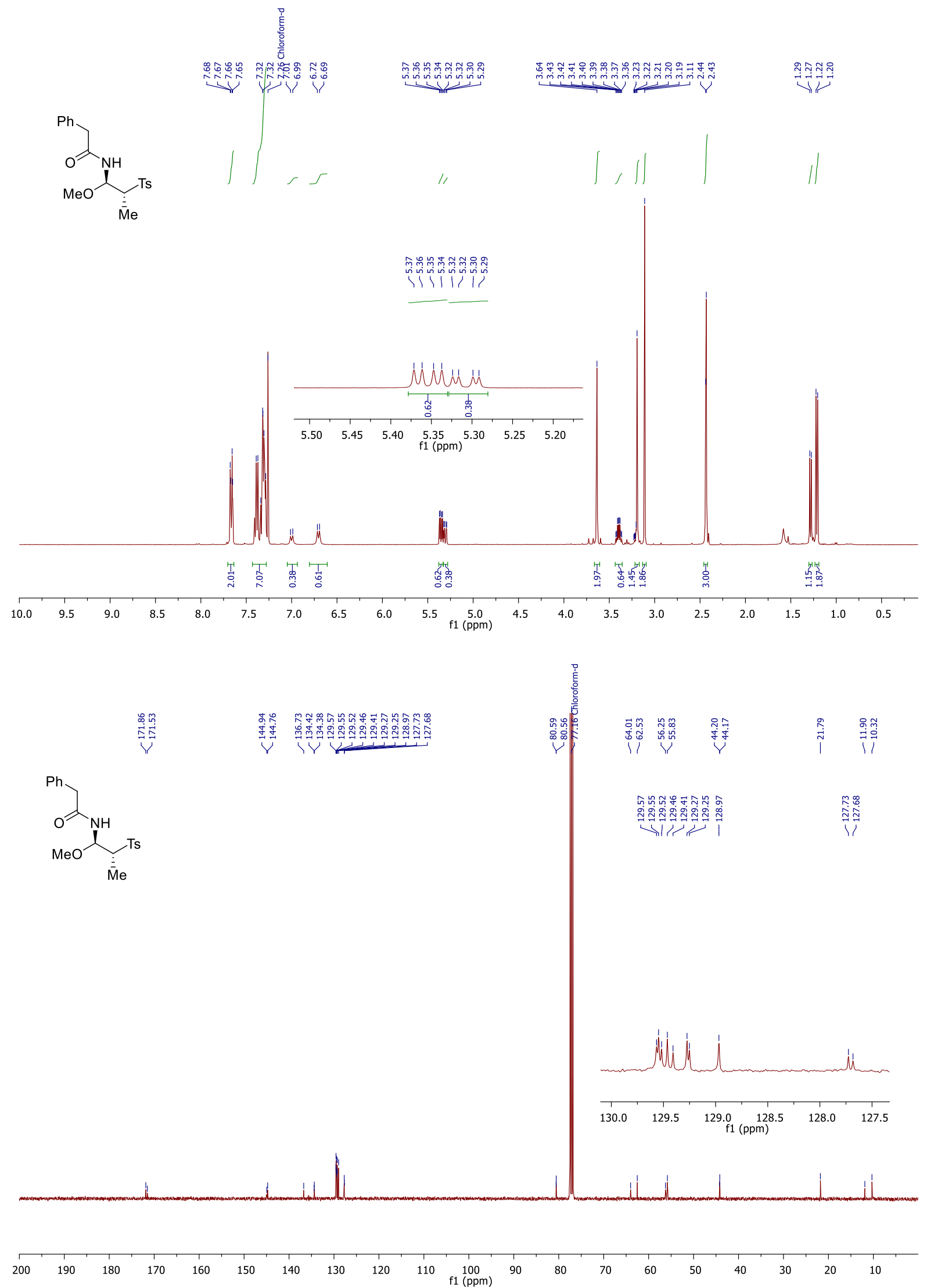

Figure S11: ${ }^{1} \mathrm{H}(400 \mathrm{MHz})$ and ${ }^{13} \mathrm{C}\left\{{ }^{1} \mathrm{H}\right\}(101 \mathrm{MHz}) \mathrm{NMR}$ spectra of $4 \mathrm{~m}$ in $\mathrm{CDCl}$. 

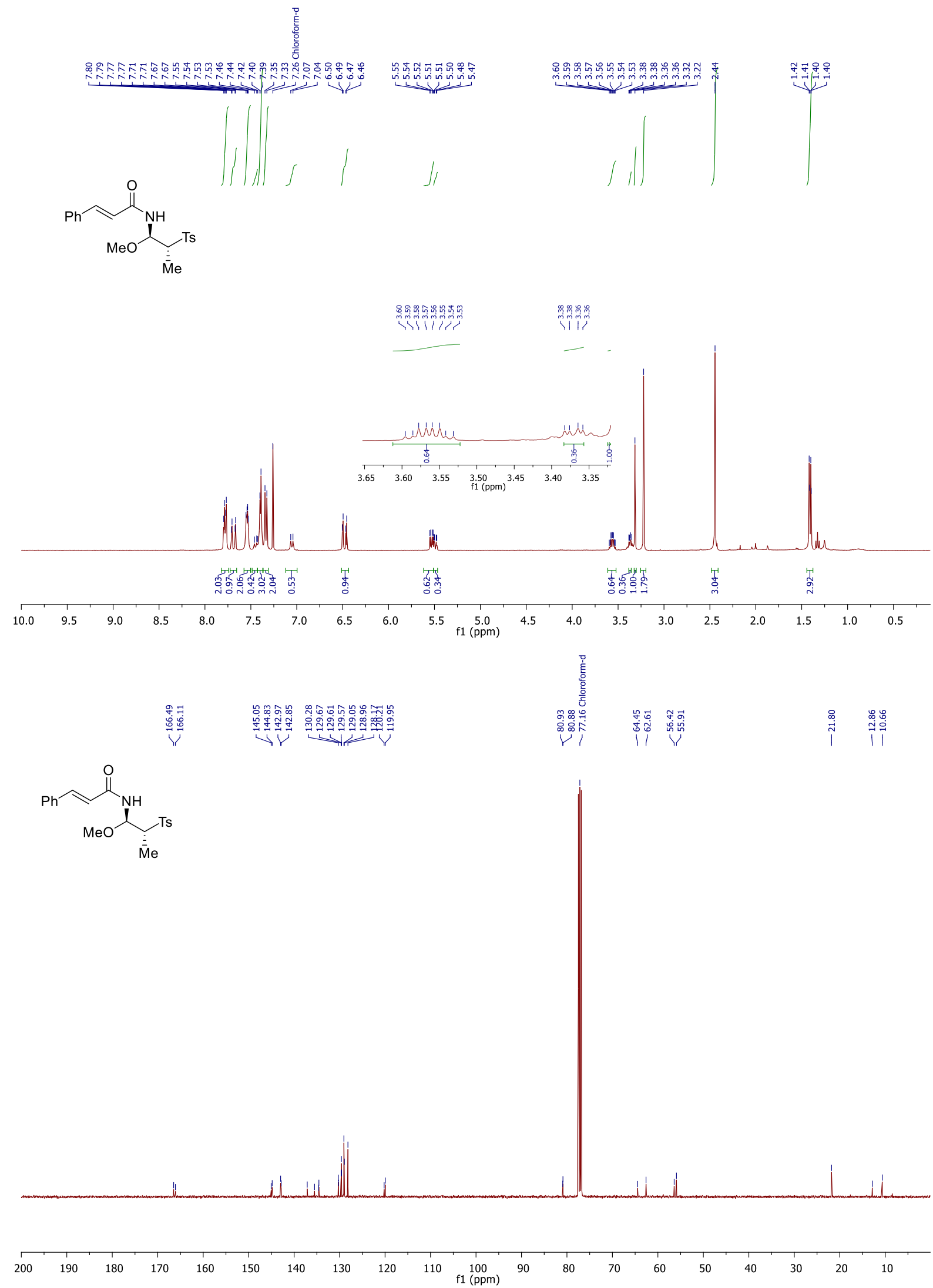

Figure S12: ${ }^{1} \mathrm{H}(400 \mathrm{MHz})$ and ${ }^{13} \mathrm{C}\left\{{ }^{1} \mathrm{H}\right\}(101 \mathrm{MHz})$ NMR spectra of $4 \mathrm{n}$ in $\mathrm{CDCl}$. 

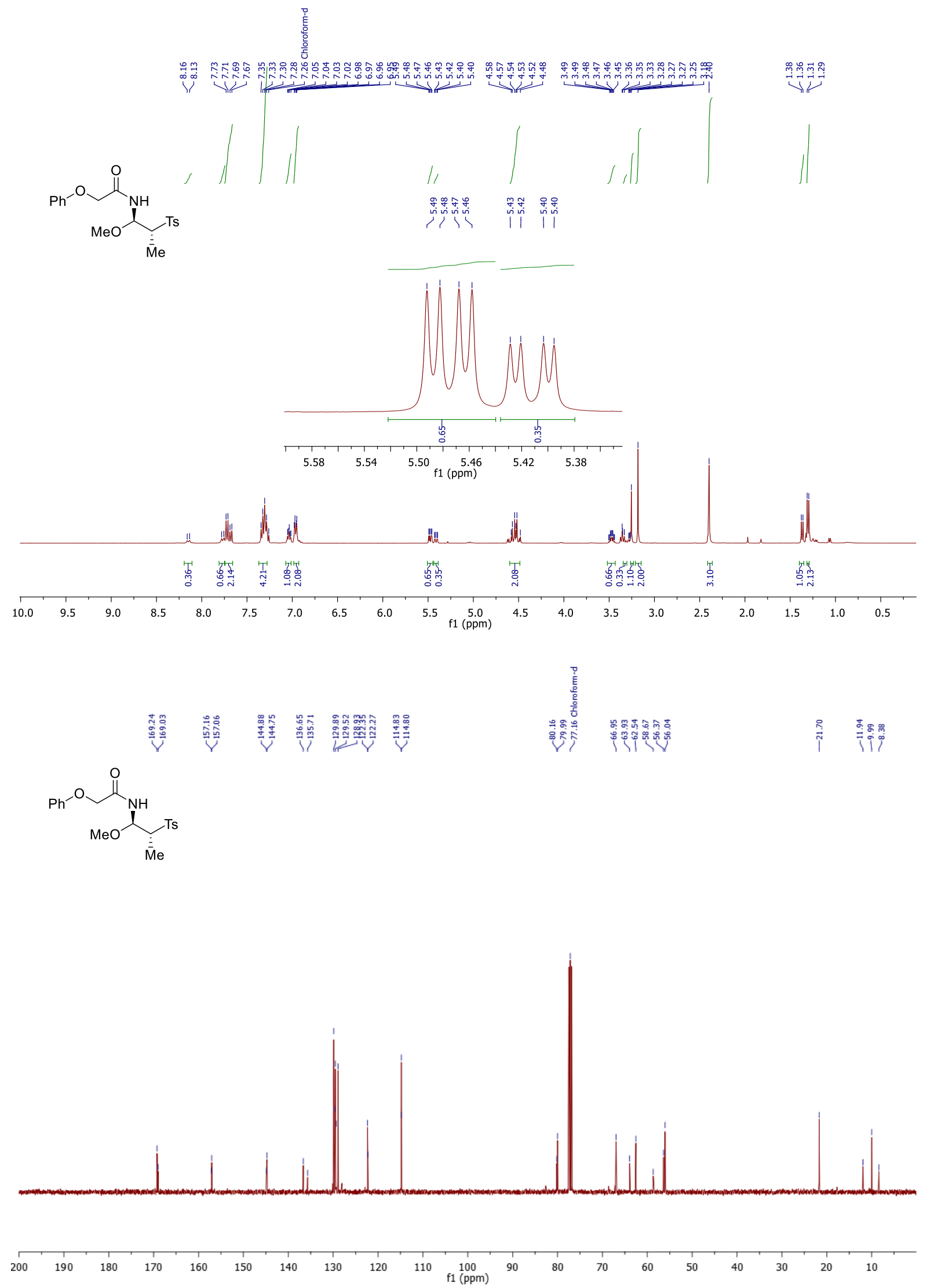

Figure S13: ${ }^{1 \mathrm{H}}(400 \mathrm{MHz})$ and ${ }^{13} \mathrm{C}\left\{{ }^{1} \mathrm{H}\right\}(101 \mathrm{MHz}) \mathrm{NMR}$ spectra of 40 in $\mathrm{CDCl}_{3}$. 

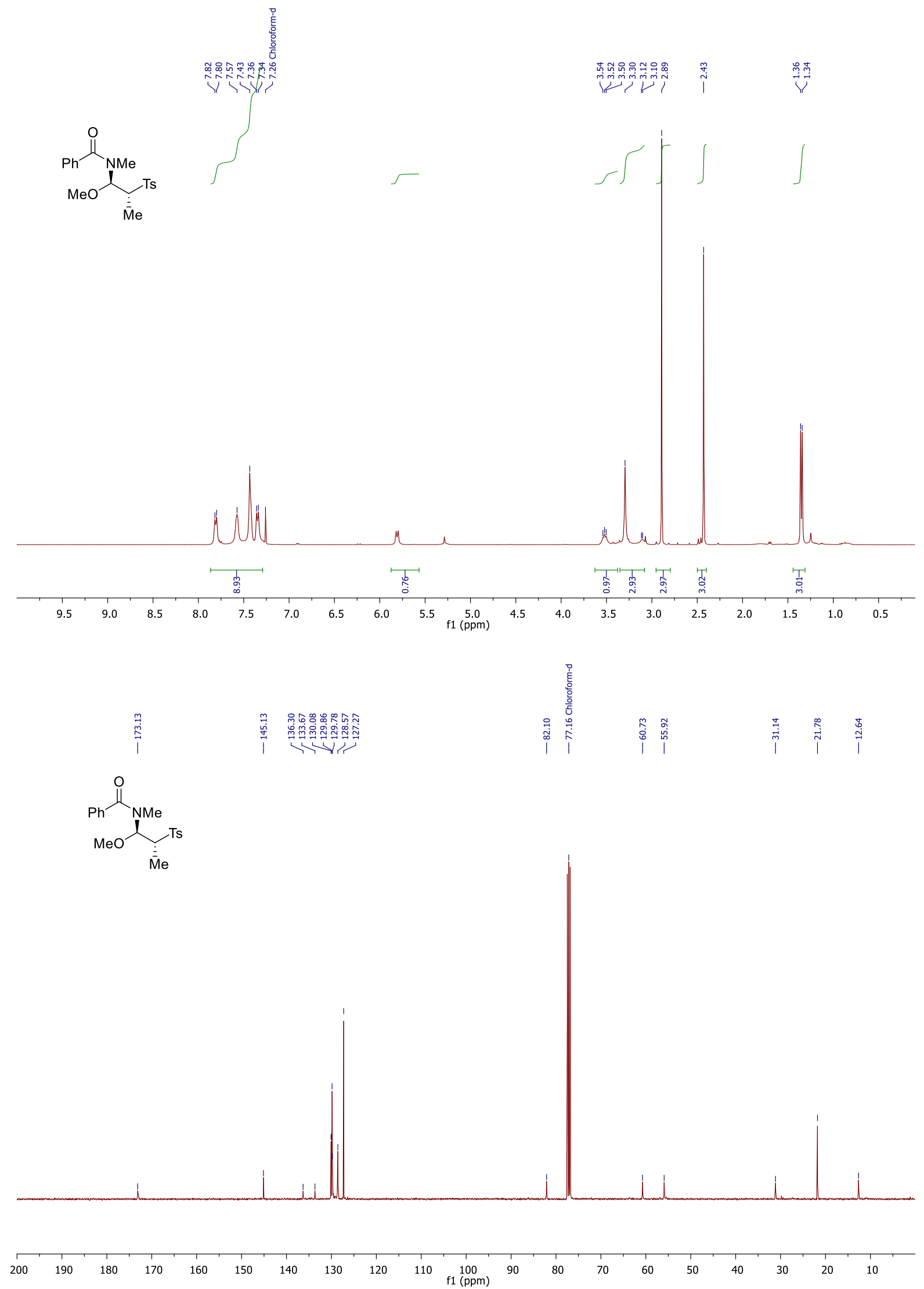

Figure S14: ${ }^{1} \mathrm{H}(400 \mathrm{MHz})$ and ${ }^{13} \mathrm{C}\left\{{ }^{1} \mathrm{H}\right\}(101 \mathrm{MHz}) \mathrm{NMR}$ spectra of $4 \mathrm{p}$ in $\mathrm{CDCl}_{3}$. 

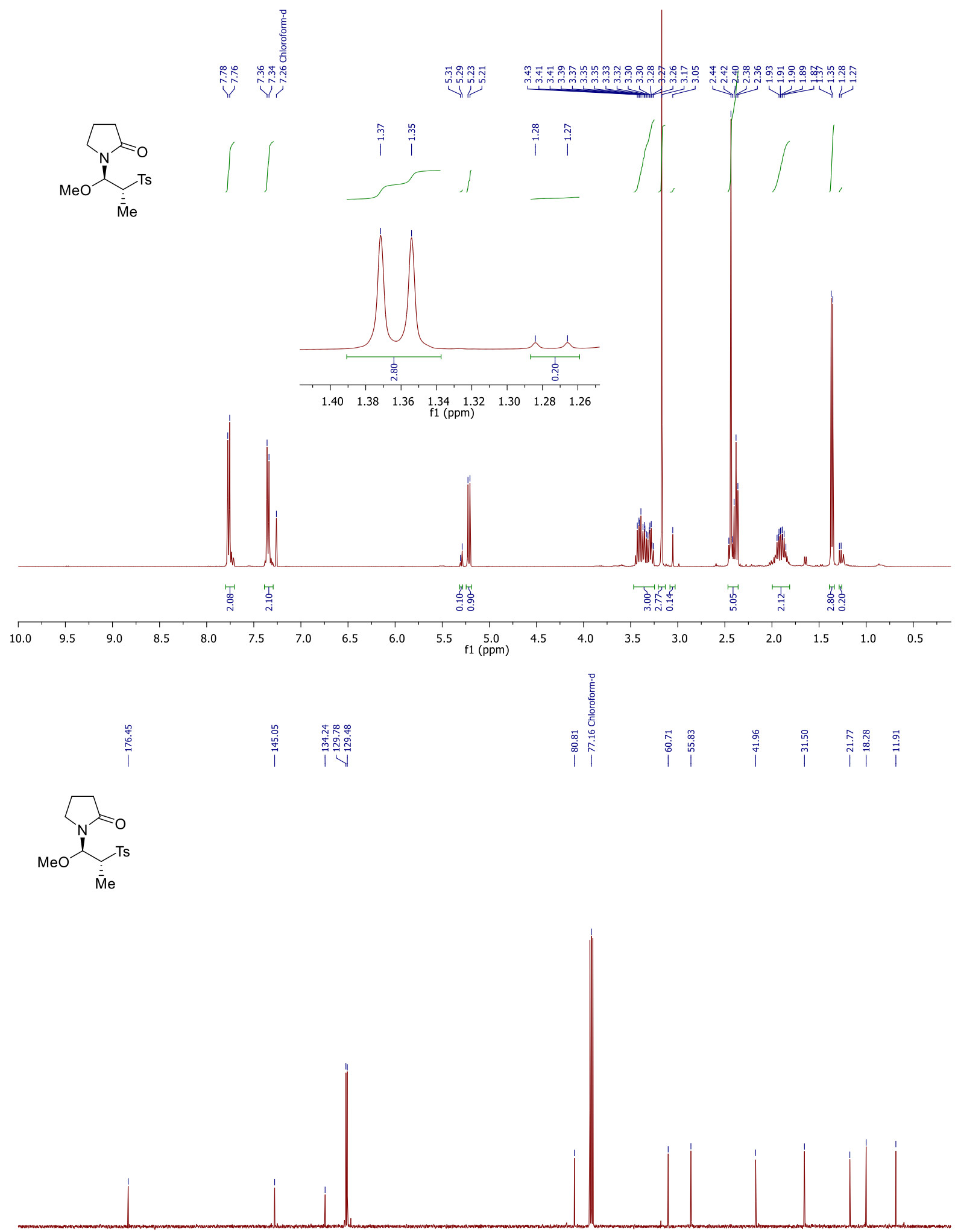

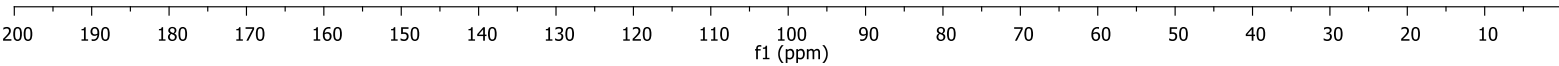

Figure S15: ${ }^{1} \mathrm{H}(400 \mathrm{MHz})$ and ${ }^{13} \mathrm{C}\left\{{ }^{1} \mathrm{H}\right\}(101 \mathrm{MHz}) \mathrm{NMR}$ spectra of $4 \mathrm{q}$ in $\mathrm{CDCl} 3$. 

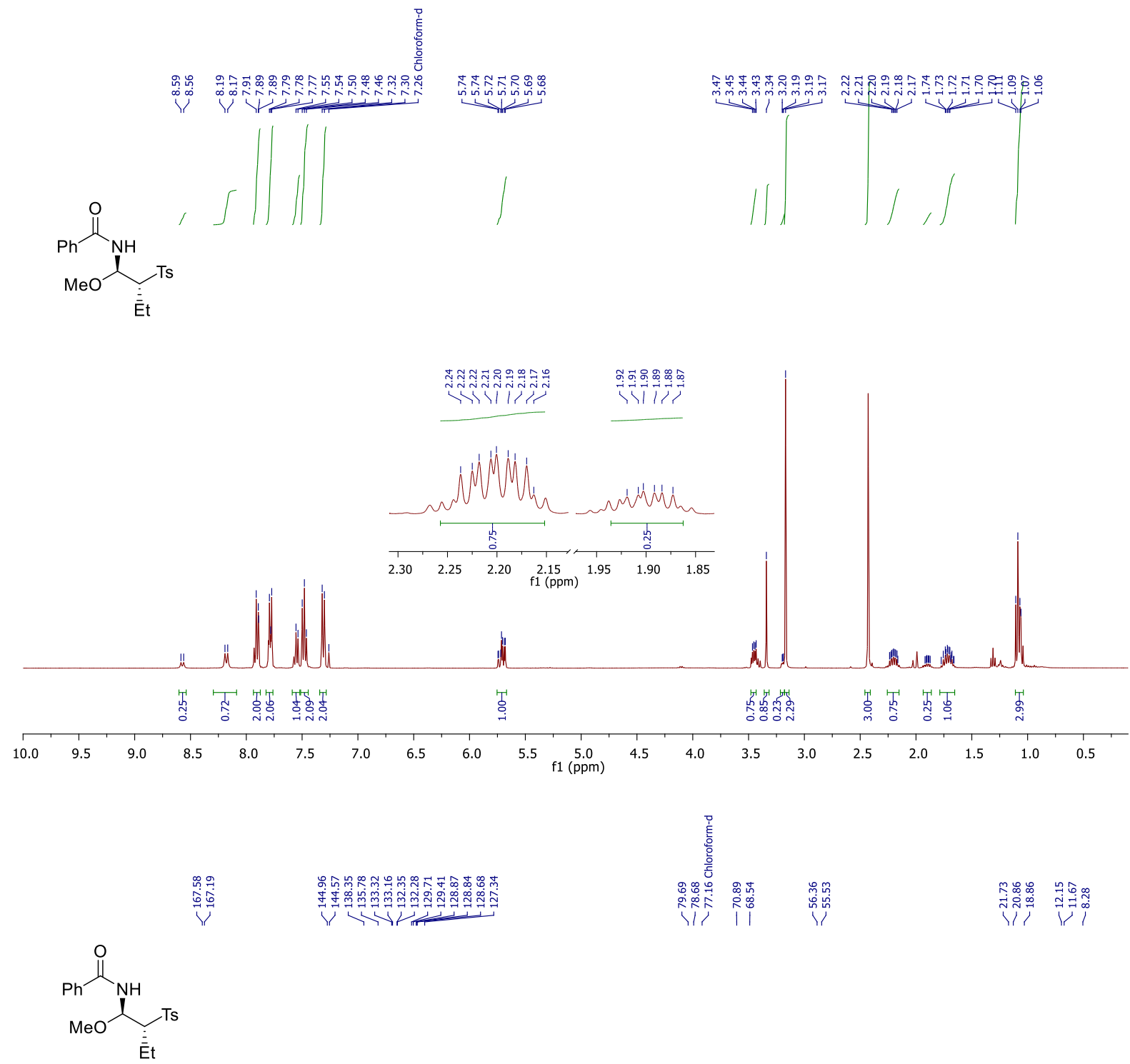

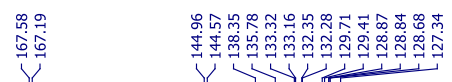

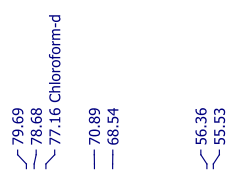

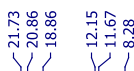
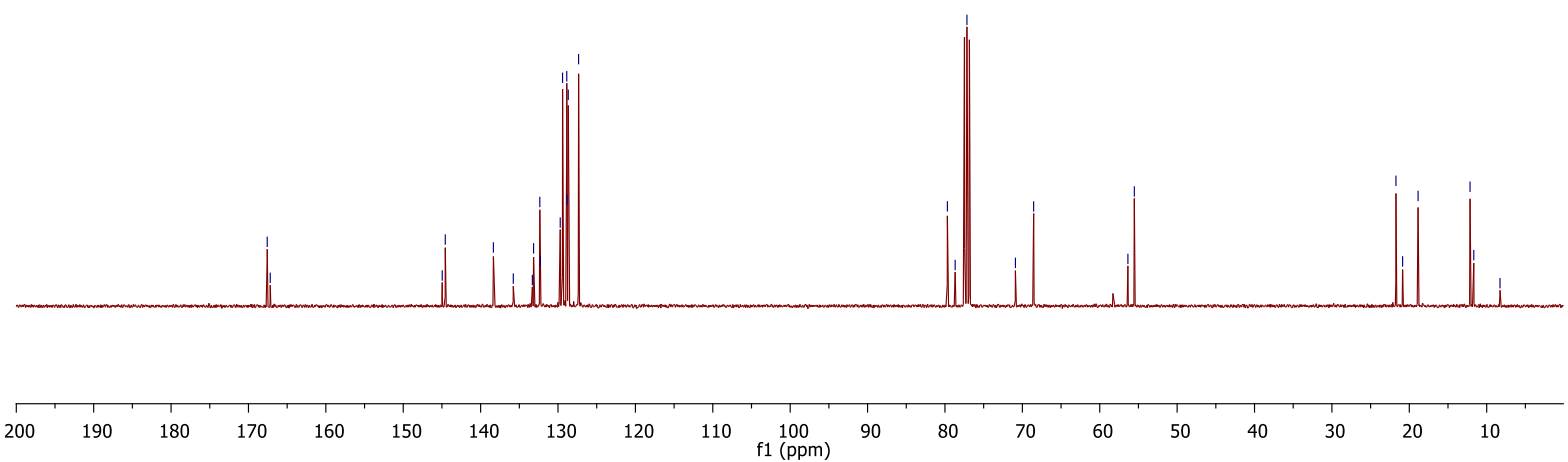

Figure S16: ${ }^{1} \mathrm{H}(400 \mathrm{MHz})$ and ${ }^{13} \mathrm{C}\left\{{ }^{1} \mathrm{H}\right\}(101 \mathrm{MHz}) \mathrm{NMR}$ spectra of $4 \mathrm{r}$ in $\mathrm{CDCl} 3$. 

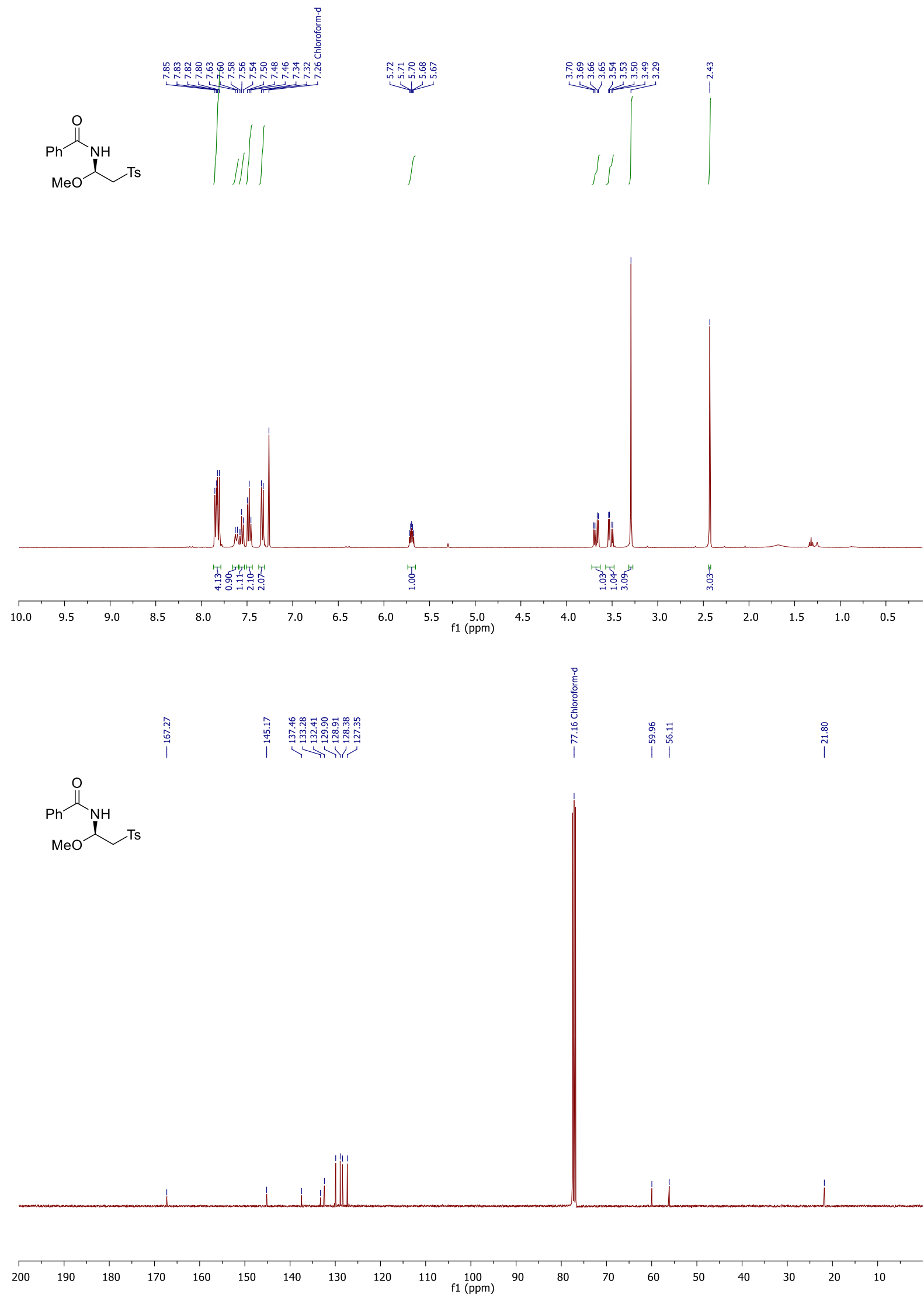

Figure S17: ${ }^{1 \mathrm{H}}(400 \mathrm{MHz})$ and ${ }^{13} \mathrm{C}\left\{{ }^{1} \mathrm{H}\right\}(101 \mathrm{MHz}) \mathrm{NMR}$ spectra of $4 \mathrm{~s}$ in $\mathrm{CDCl}$. 

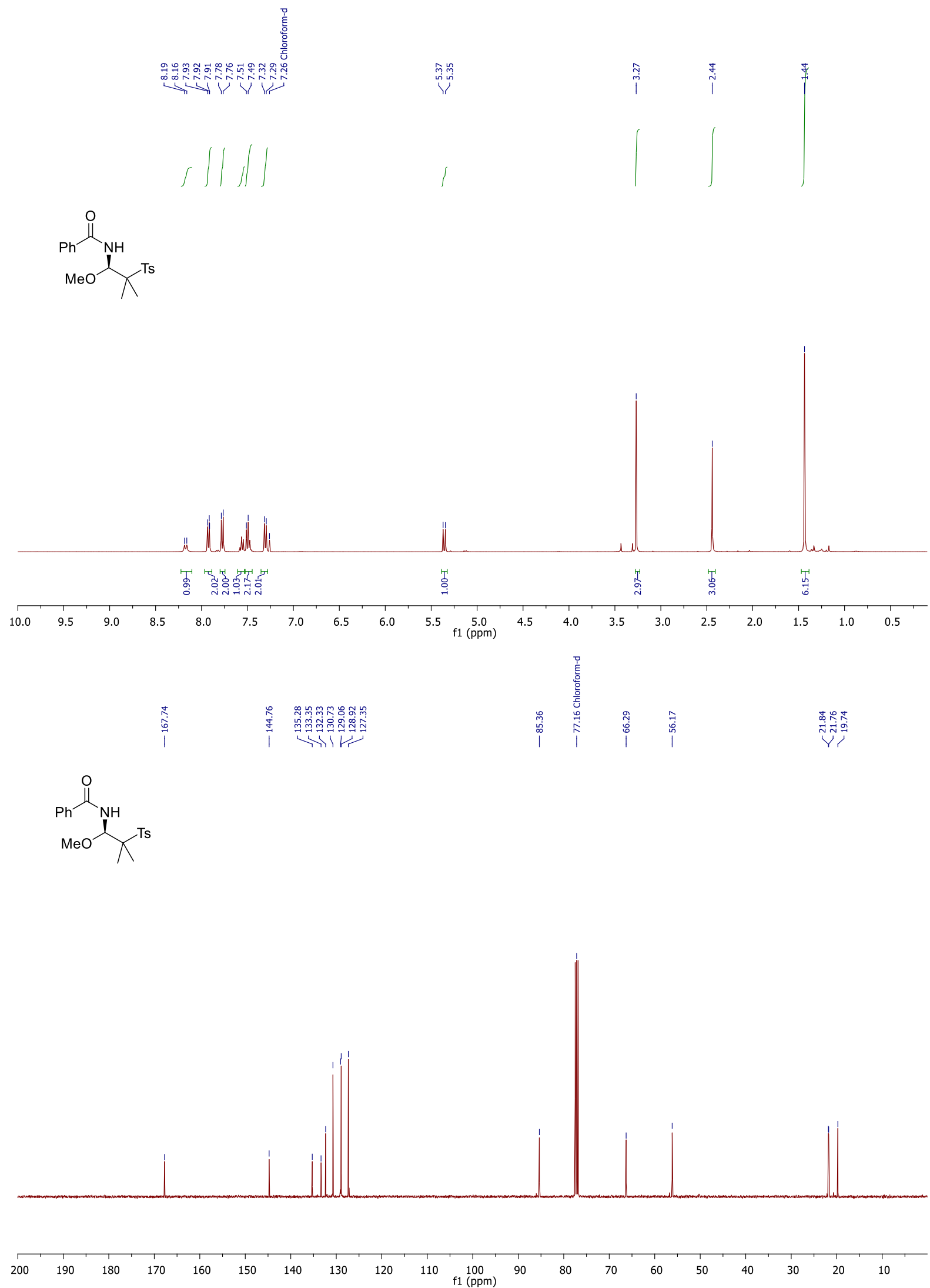

Figure S18: ${ }^{1} \mathrm{H}(400 \mathrm{MHz})$ and ${ }^{13} \mathrm{C}\left\{{ }^{1} \mathrm{H}\right\}(101 \mathrm{MHz}) \mathrm{NMR}$ spectra of $4 \mathrm{t}$ in $\mathrm{CDCl}$. 

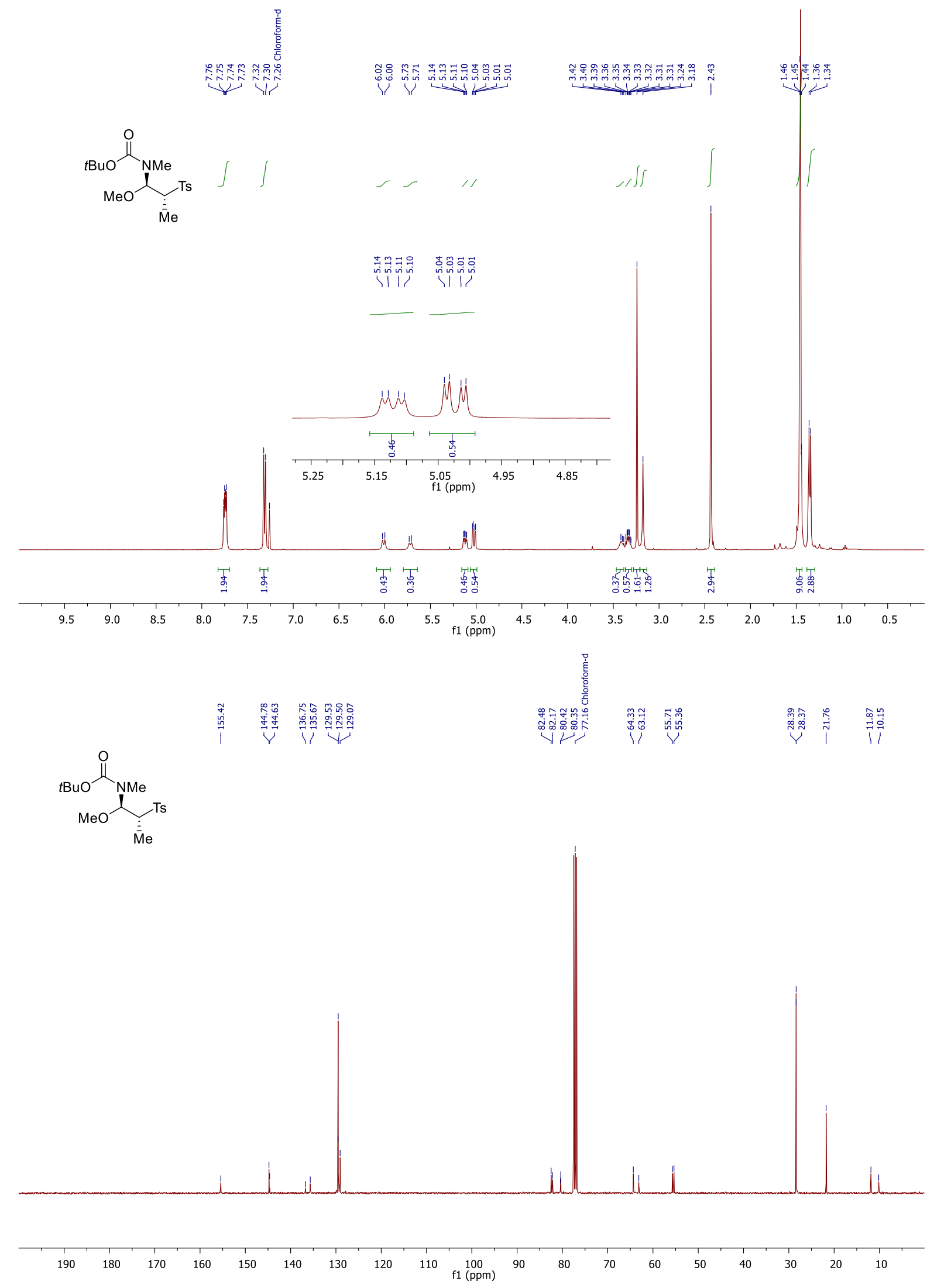

Figure S19: ${ }^{1} \mathrm{H}(400 \mathrm{MHz})$ and ${ }^{13} \mathrm{C}\left\{{ }^{1} \mathrm{H}\right\}(101 \mathrm{MHz})$ NMR spectra of $4 u$ in $\mathrm{CDCl}_{3}$. 

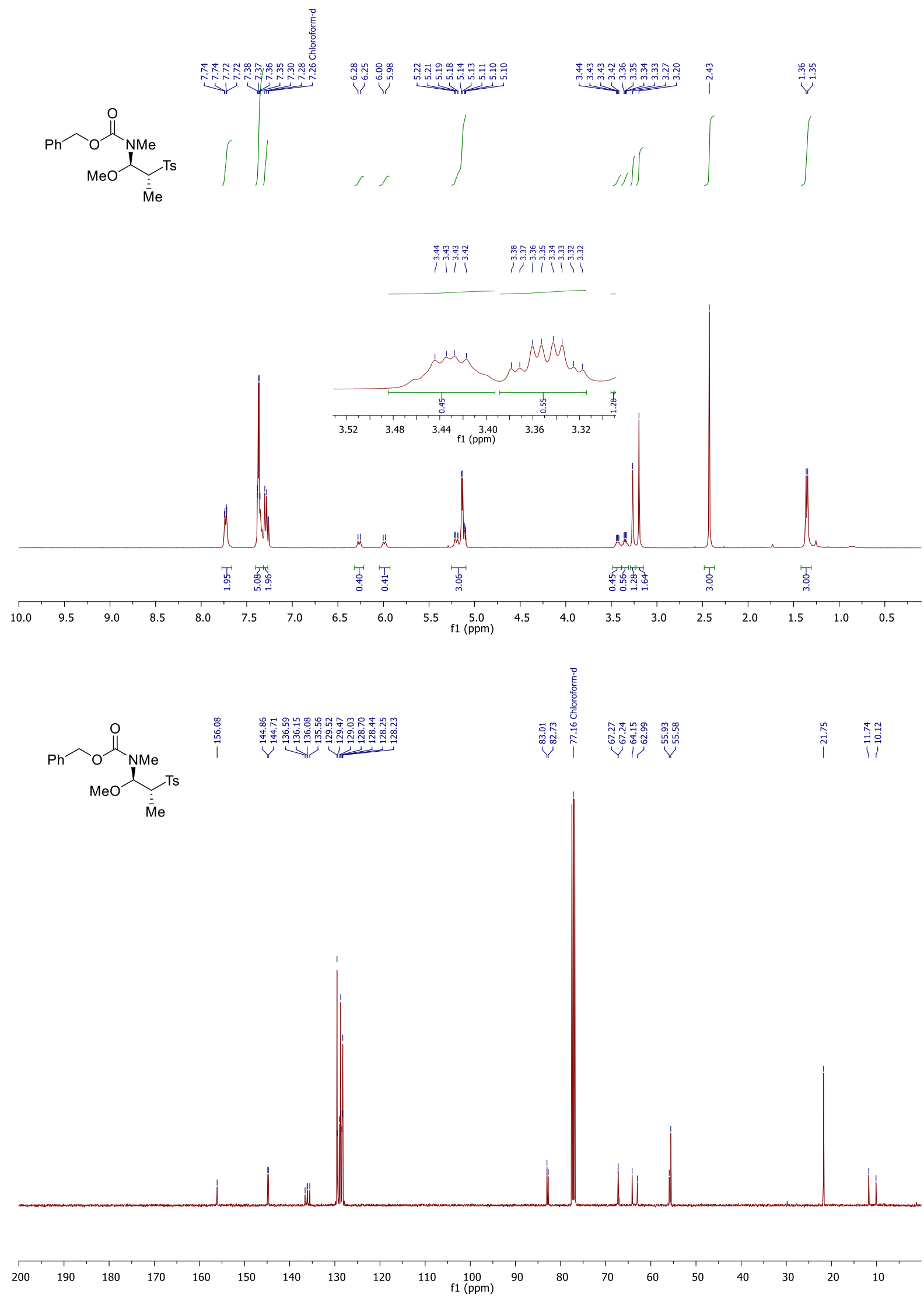

Figure S2O: ${ }^{1} \mathrm{H}(400 \mathrm{MHz})$ and ${ }^{13} \mathrm{C}\left\{{ }^{1} \mathrm{H}\right\}(101 \mathrm{MHz}) \mathrm{NMR}$ spectra of $4 \mathrm{v}$ in $\mathrm{CDCl}_{3}$. 


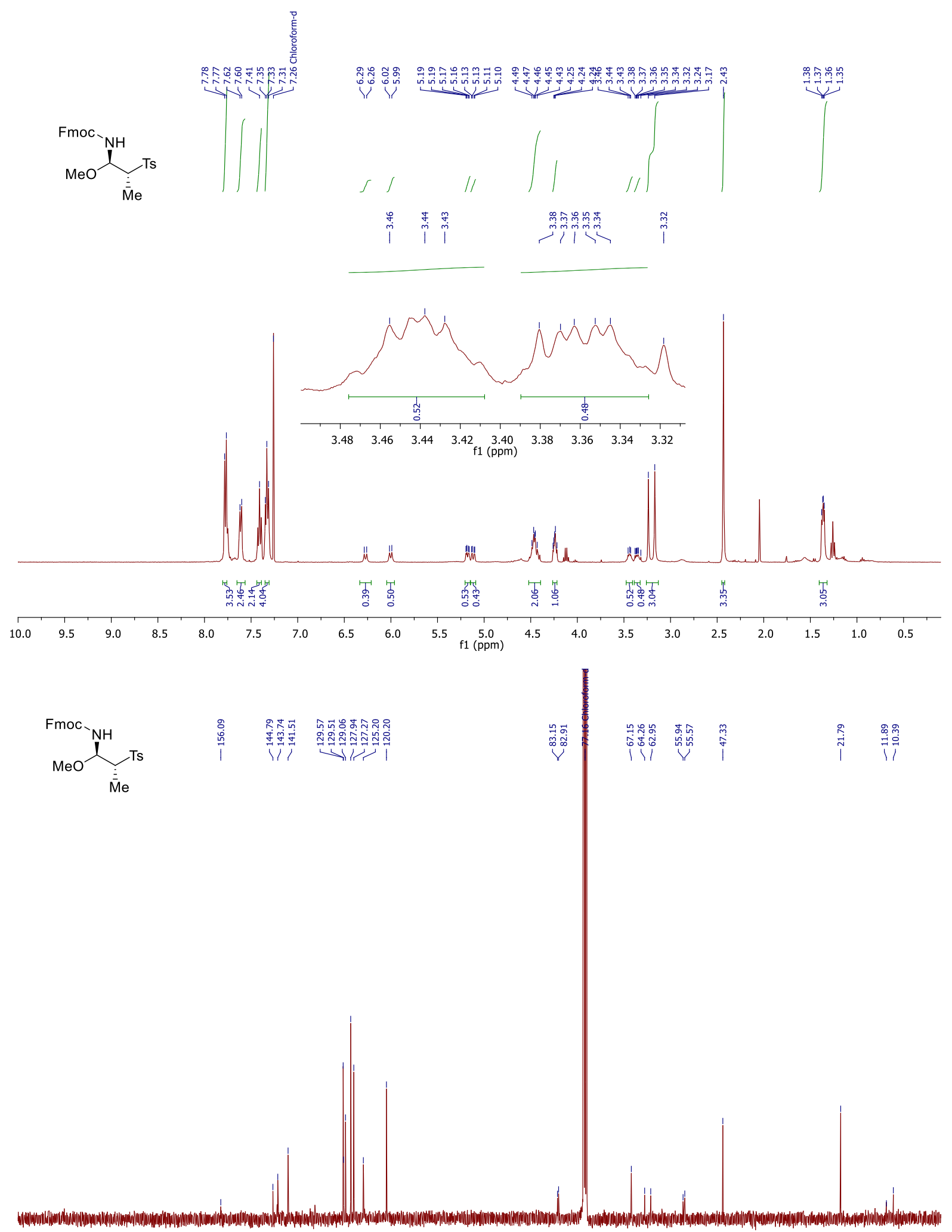

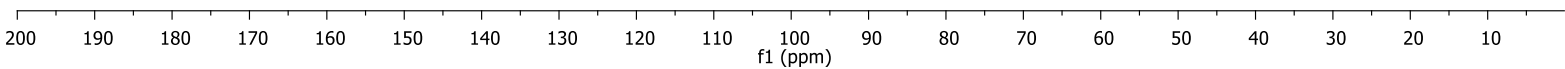

Figure S21: ${ }^{1} \mathrm{H}(400 \mathrm{MHz})$ and ${ }^{13} \mathrm{C}\left\{{ }^{1} \mathrm{H}\right\}(101 \mathrm{MHz}) \mathrm{NMR}$ spectra of $4 \mathbf{w}$ in $\mathrm{CDCl}_{3}$. 

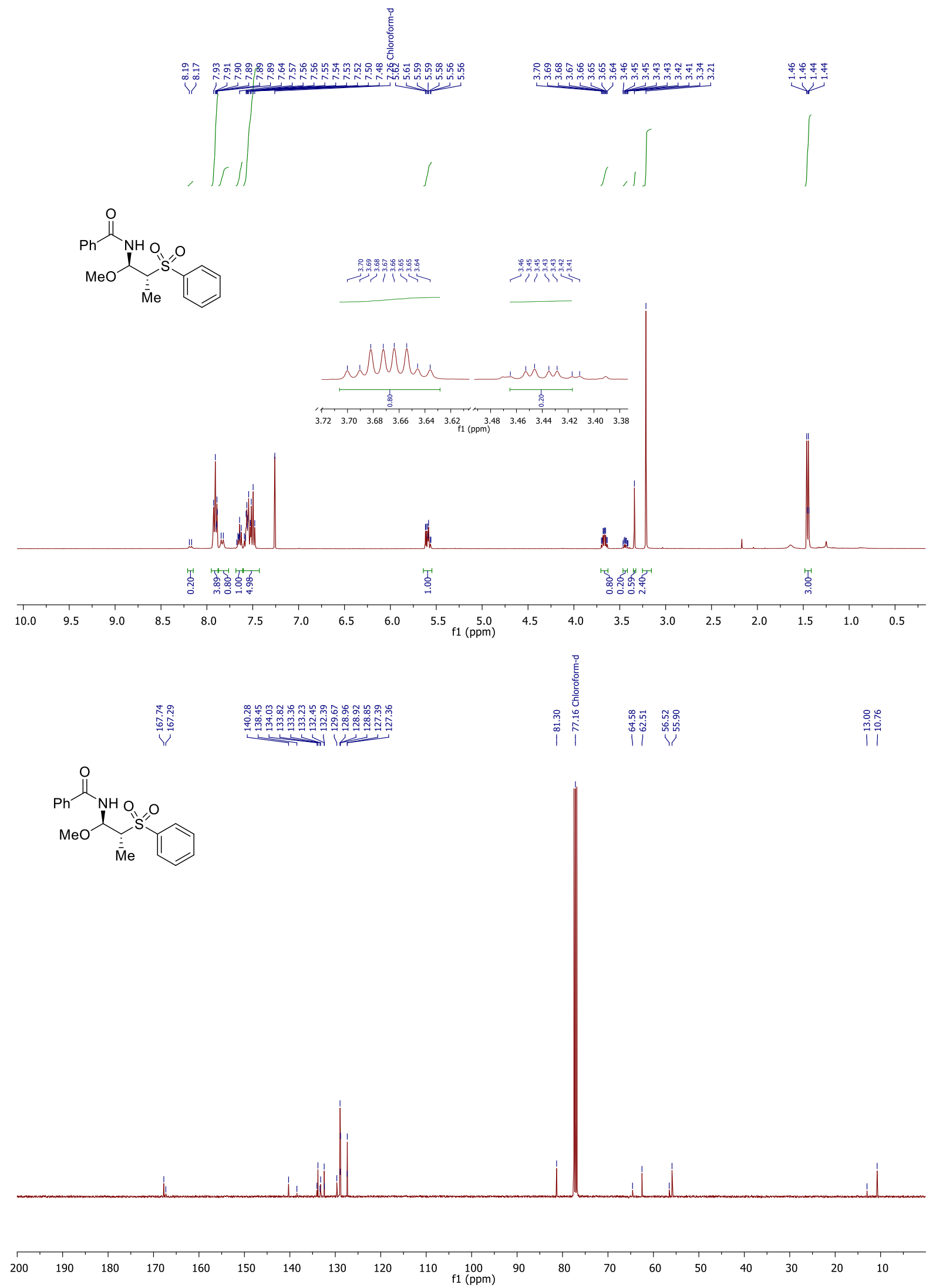

Figure S22: ${ }^{1} \mathrm{H}(400 \mathrm{MHz})$ and ${ }^{13} \mathrm{C}\left\{{ }^{1} \mathrm{H}\right\}(101 \mathrm{MHz}) \mathrm{NMR}$ spectra of $6 \boldsymbol{b}$ in $\mathrm{CDCl}_{3}$. 

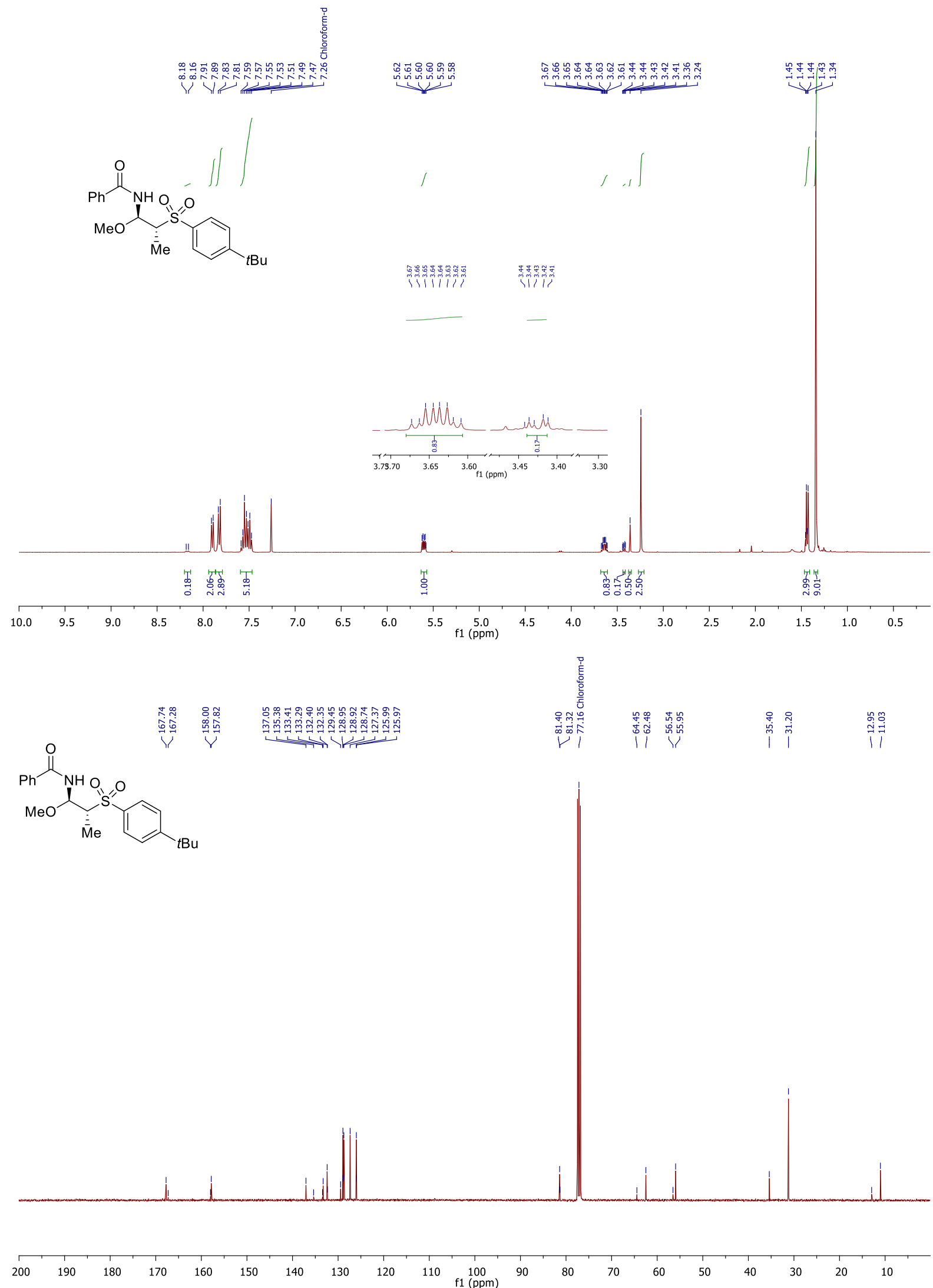

Figure S23: ${ }^{1} \mathrm{H}(400 \mathrm{MHz})$ and ${ }^{13} \mathrm{C}\left\{{ }^{1} \mathrm{H}\right\}(101 \mathrm{MHz}) \mathrm{NMR}$ spectra of $6 \mathrm{c}$ in $\mathrm{CDCl}$. 

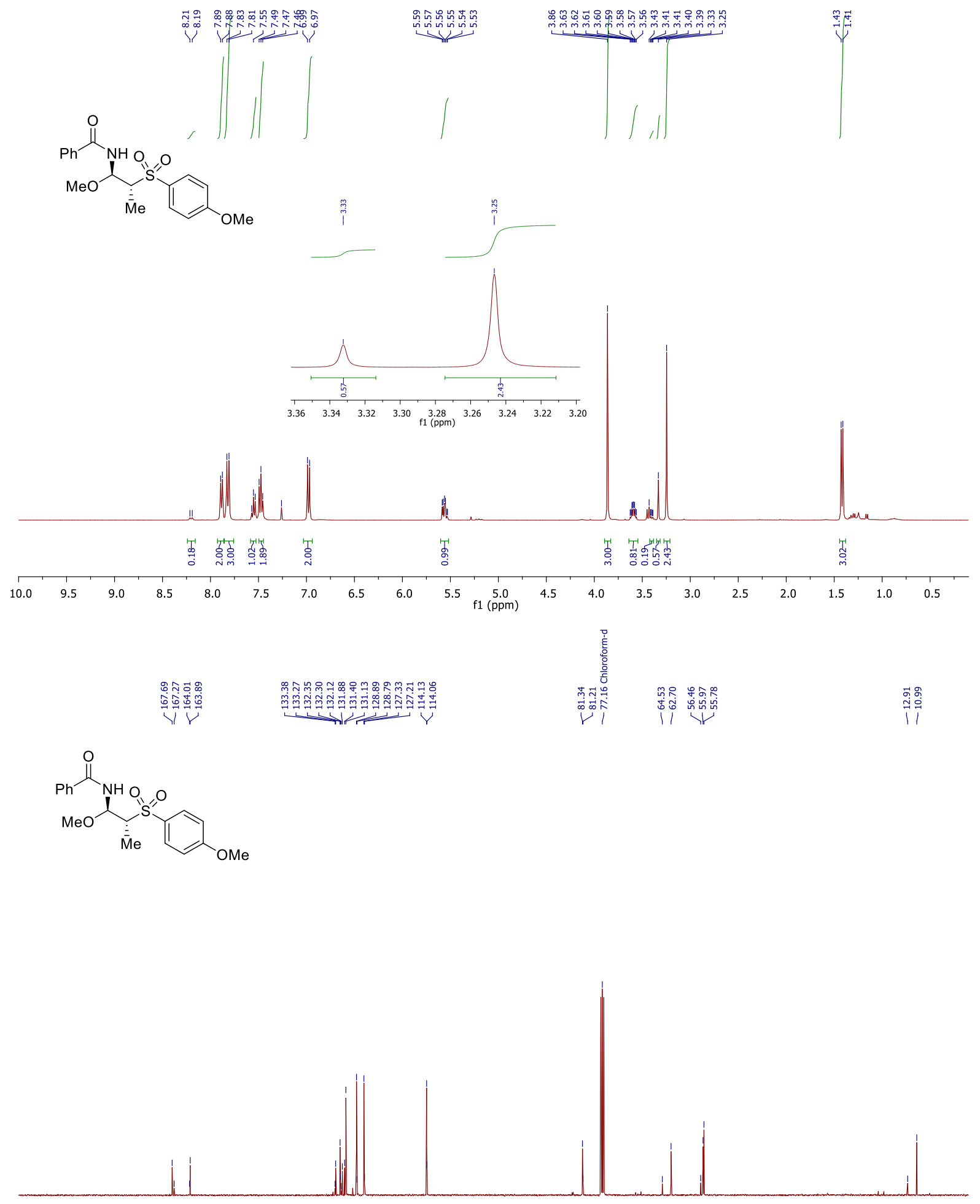

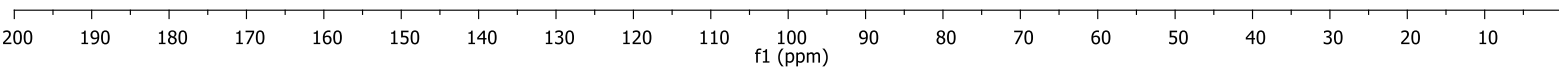

Figure S24: ${ }^{1} \mathrm{H}(400 \mathrm{MHz})$ and ${ }^{13} \mathrm{C}\left\{{ }^{1} \mathrm{H}\right\}(101 \mathrm{MHz}) \mathrm{NMR}$ spectra of $6 \mathrm{~d}$ in $\mathrm{CDCl} 3$. 

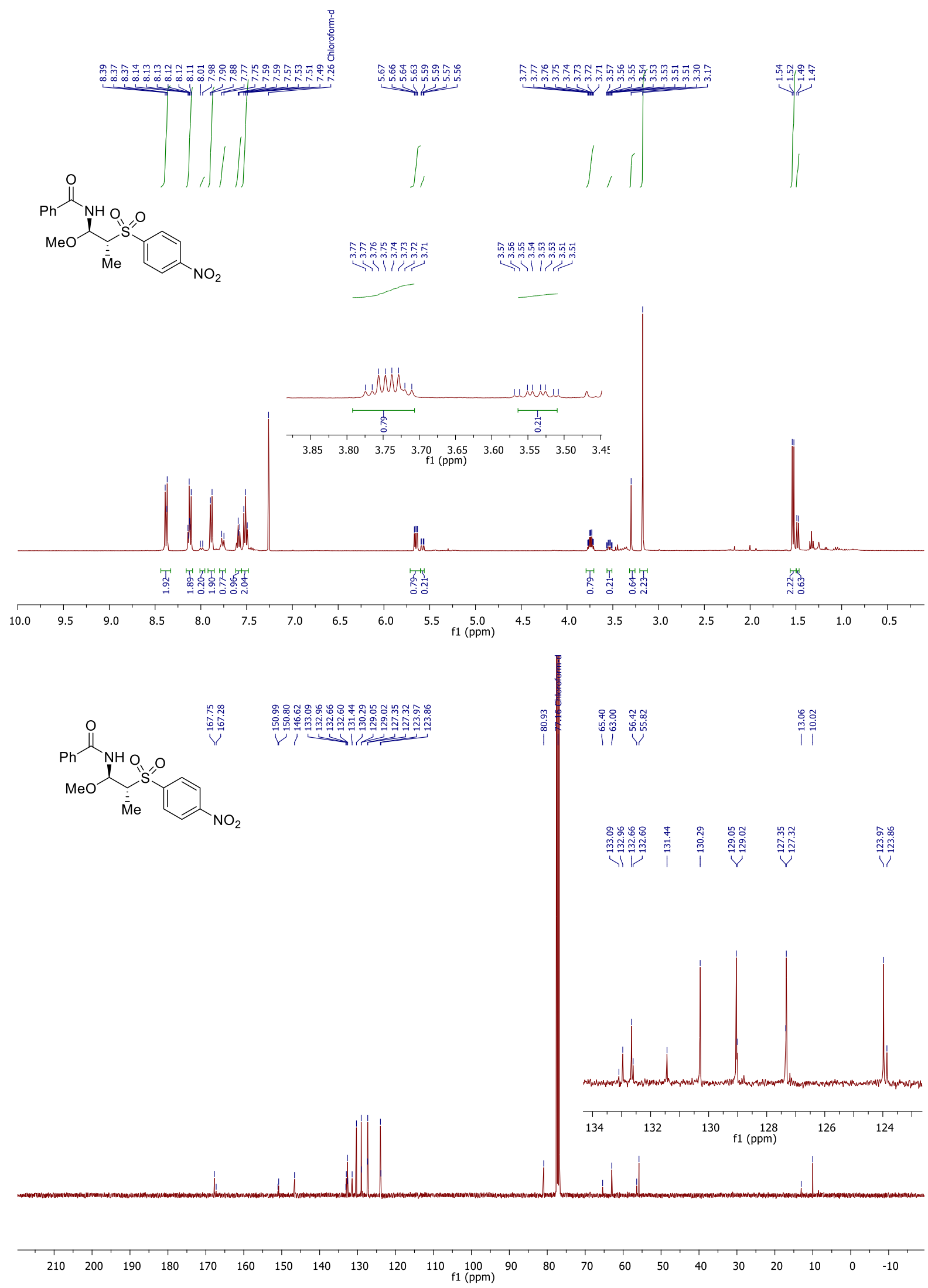

Figure S25: ${ }^{1} \mathrm{H}(400 \mathrm{MHz})$ and ${ }^{13} \mathrm{C}\left\{{ }^{1} \mathrm{H}\right\}(101 \mathrm{MHz})$ NMR spectra of $6 \boldsymbol{e}$ in $\mathrm{CDCl}_{3}$. 


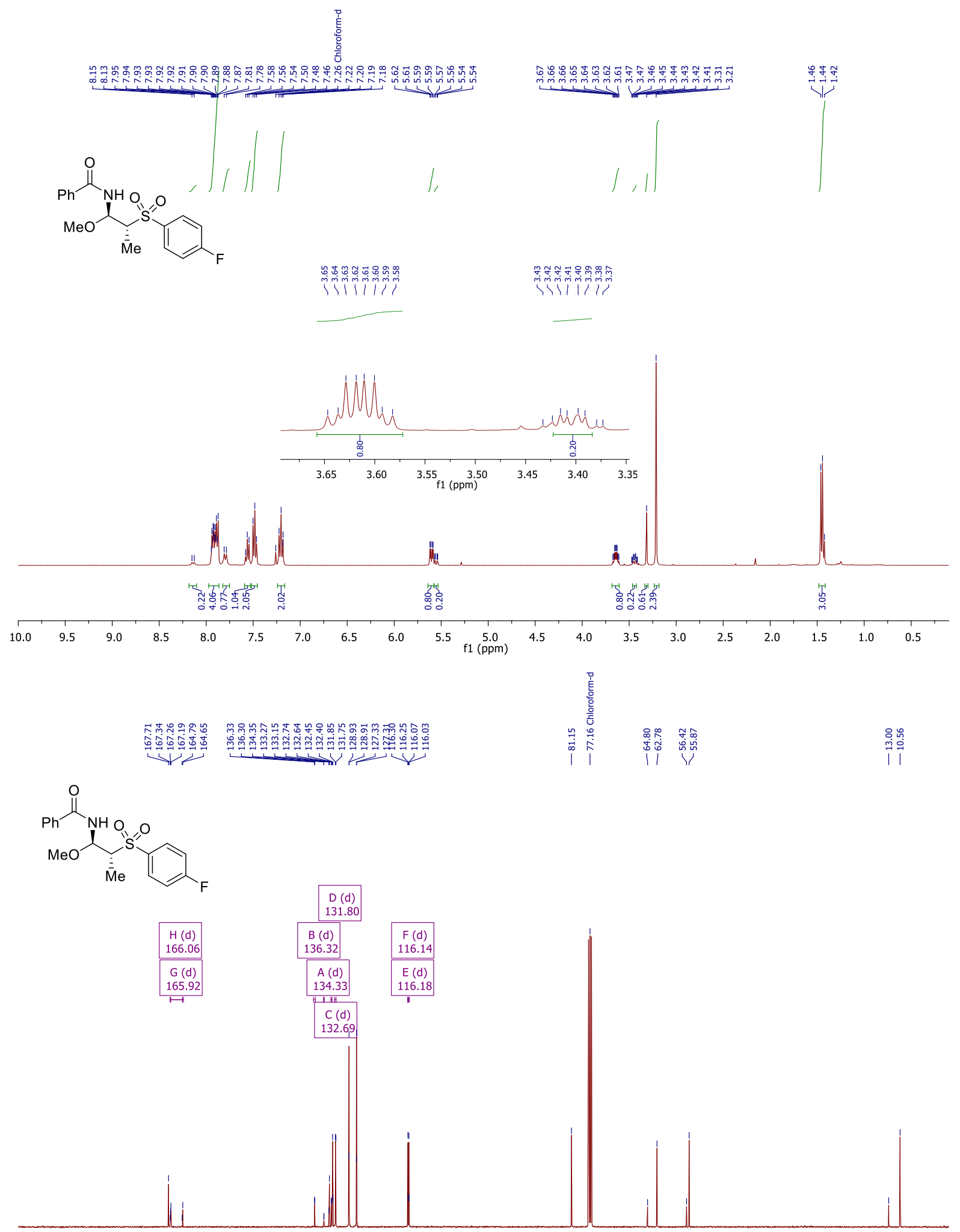

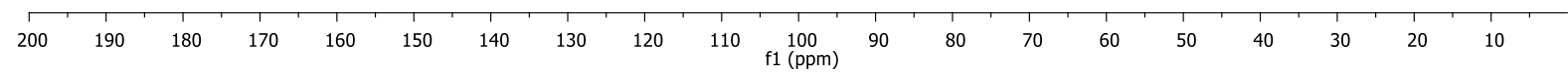



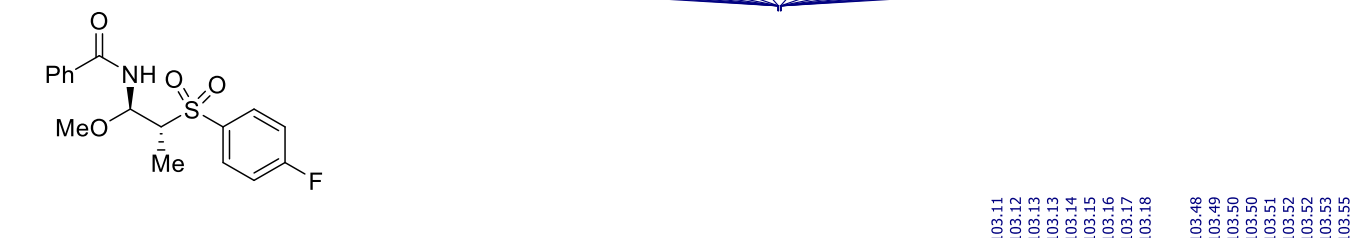

作
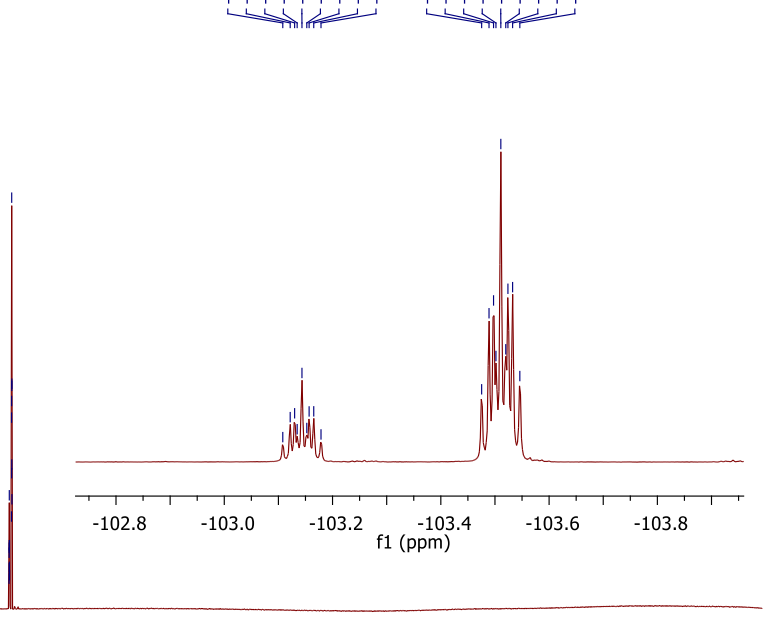

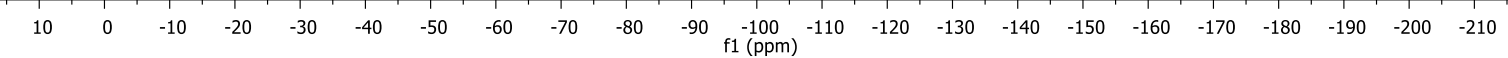

Figure S26: ${ }^{1} \mathrm{H}(400 \mathrm{MHz}),{ }^{13} \mathrm{C}\left\{{ }^{1} \mathrm{H}\right\}(101 \mathrm{MHz})$ and ${ }^{19} \mathrm{~F}\left\{{ }^{1} \mathrm{H}\right\}(376 \mathrm{MHz}) \mathrm{NMR}$ spectra of $6 \mathrm{fin} \mathrm{CDCl} 3$. 

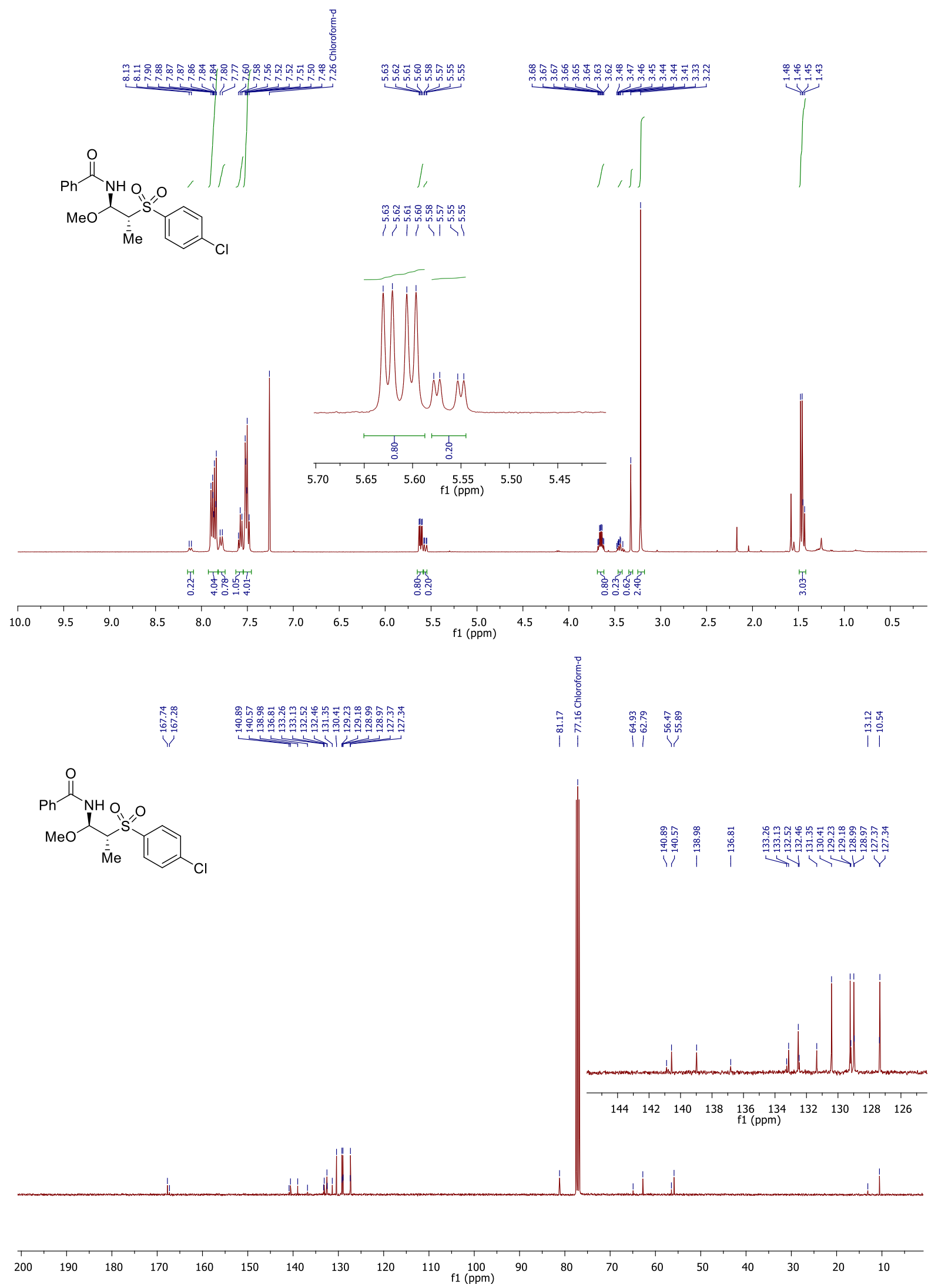

Figure S27: ${ }^{1} \mathrm{H}(400 \mathrm{MHz})$ and ${ }^{13} \mathrm{C}\left\{{ }^{1} \mathrm{H}\right\}(101 \mathrm{MHz}) \mathrm{NMR}$ spectra of $6 \mathrm{~g}$ in $\mathrm{CDCl}_{3}$. 


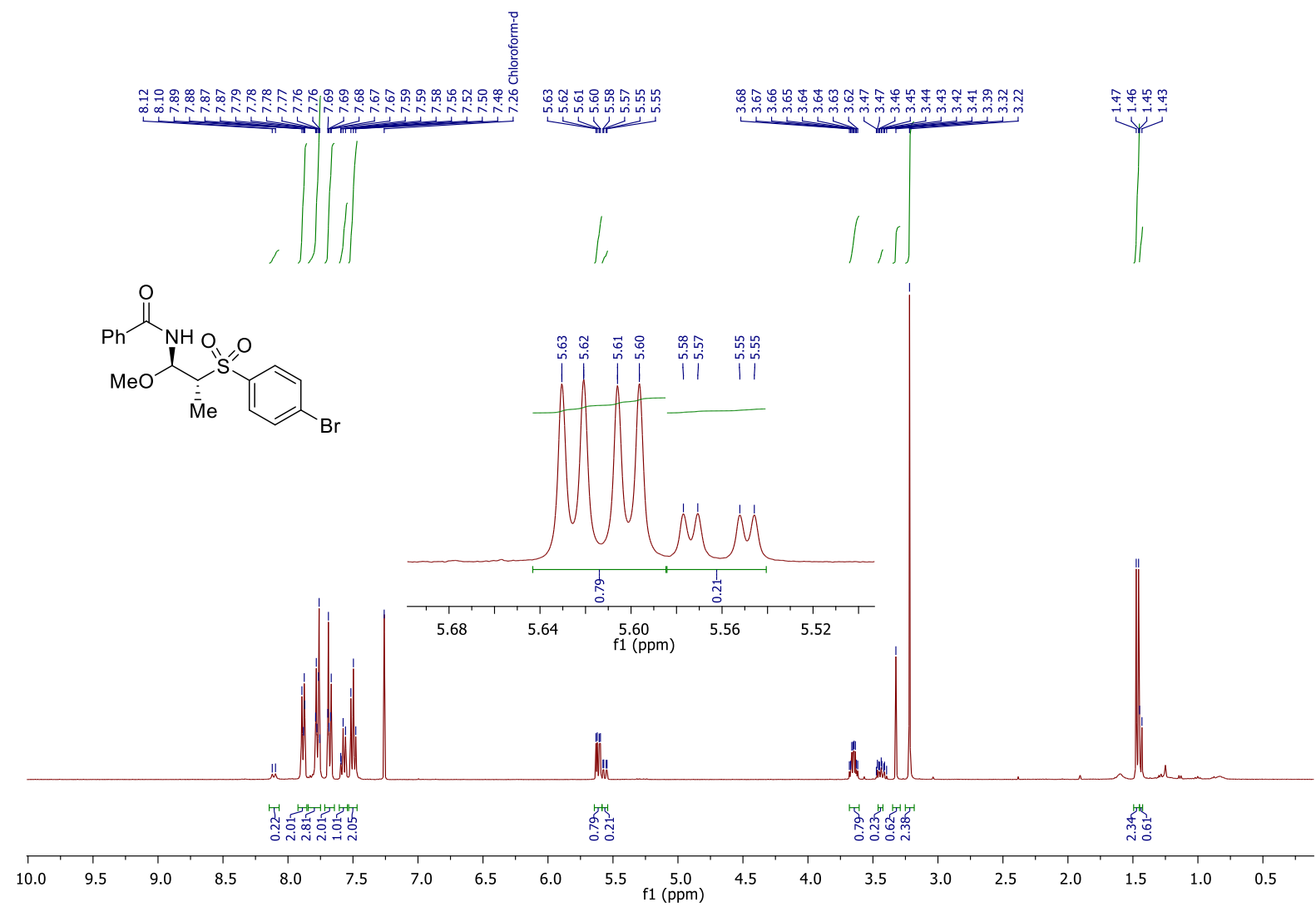

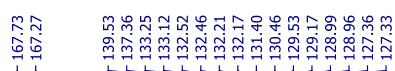

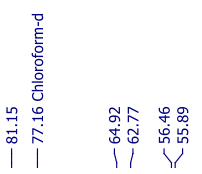

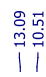
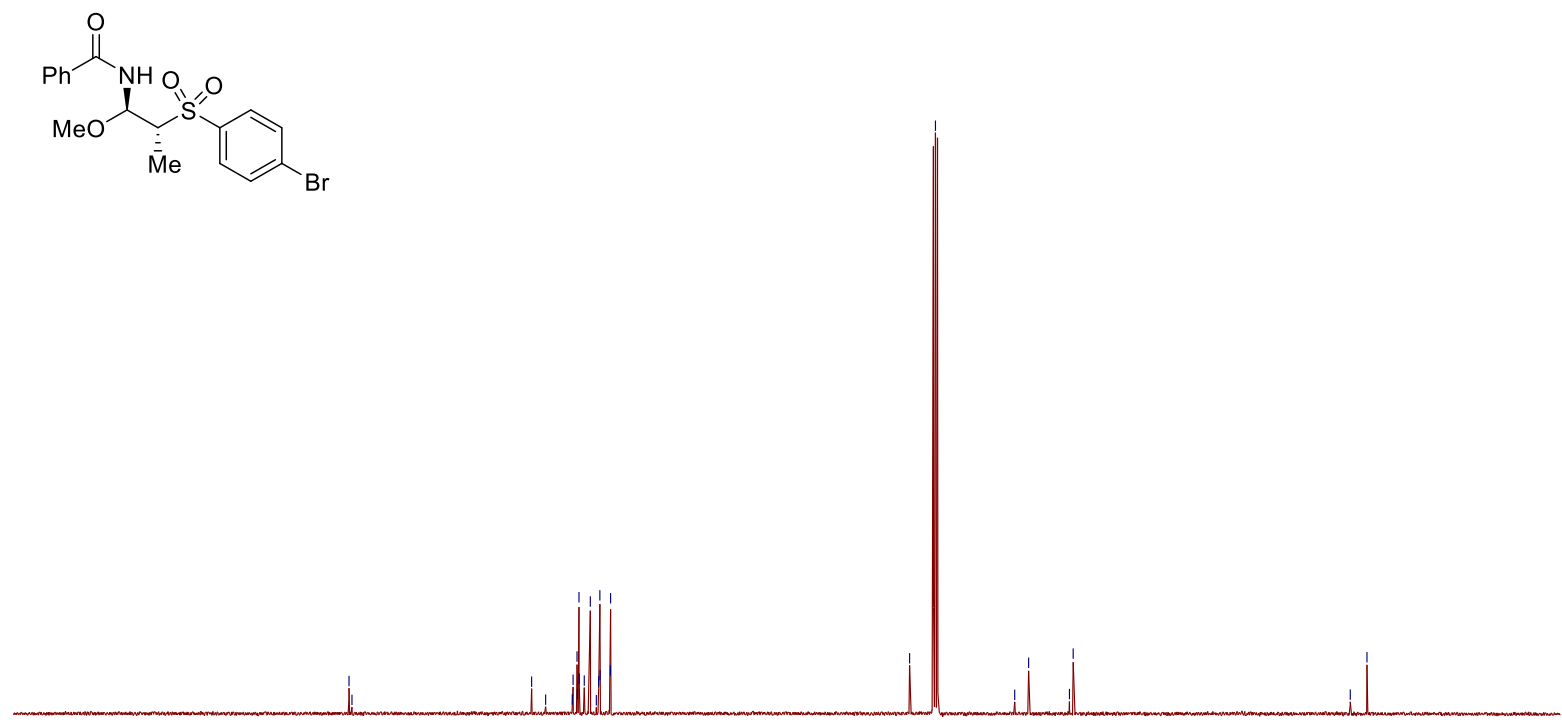

$\begin{array}{llllllllllllllllllllllllllllllllll}210 & 200 & 190 & 180 & 170 & 160 & 150 & 140 & 130 & 120 & 110 & 100 & 90 & 80 & 70 & 60 & 50 & 40 & 30 & 20 & 10 & 0 & -10\end{array}$

Figure S28: ${ }^{1} \mathrm{H}(400 \mathrm{MHz})$ and ${ }^{13} \mathrm{C}\left\{{ }^{1} \mathrm{H}\right\}(101 \mathrm{MHz}) \mathrm{NMR}$ spectra of $6 \mathrm{~h}$ in $\mathrm{CDCl}_{3}$. 

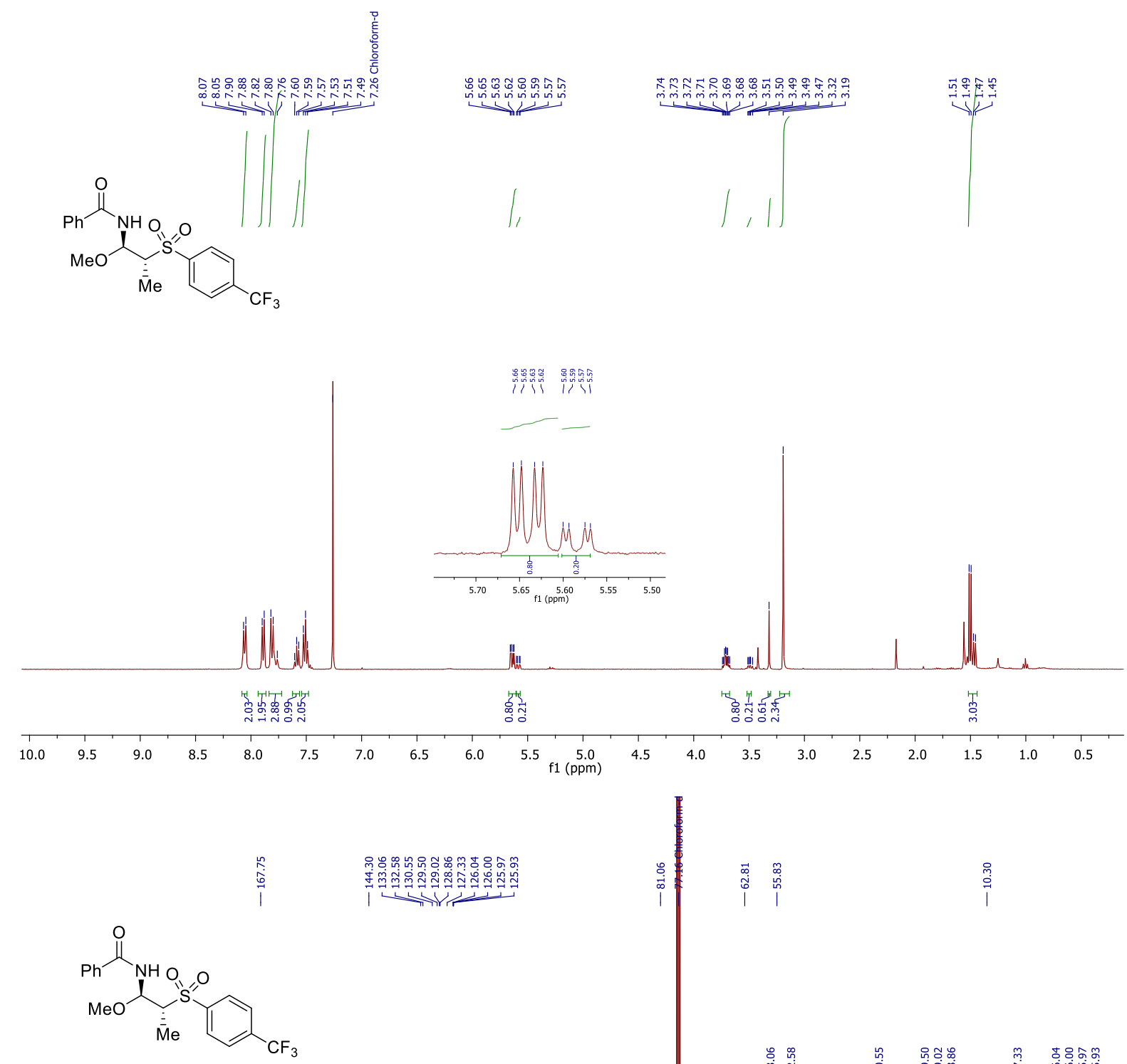

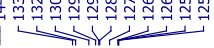

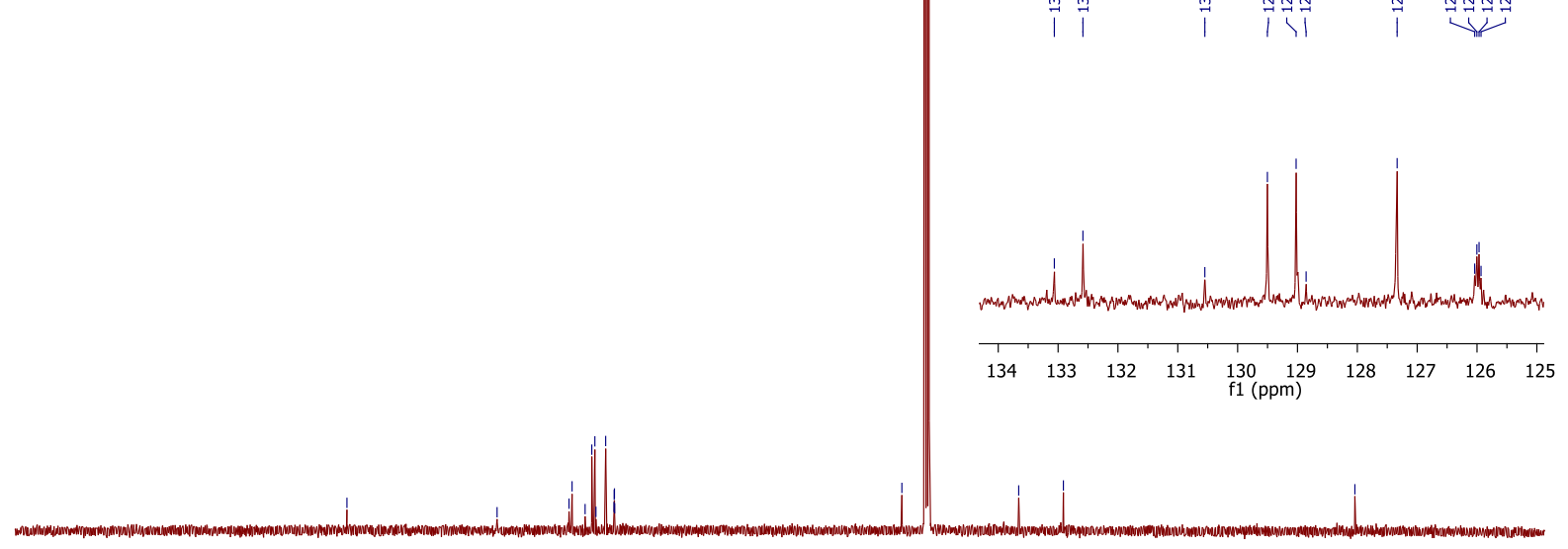

$\begin{array}{llllllllllllllllllllllllllll}210 & 200 & 190 & 180 & 170 & 160 & 150 & 140 & 130 & 120 & 110 & 100 & 90 & 80 & 70 & 60 & 50 & 40 & 30 & 20 & 10 & 0 & -10\end{array}$ 


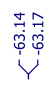<smiles>CO[C@H](NC(=O)c1ccccc1)[C@@H](C)S(=O)(=O)c1ccc(C(F)(F)F)cc1</smiles>

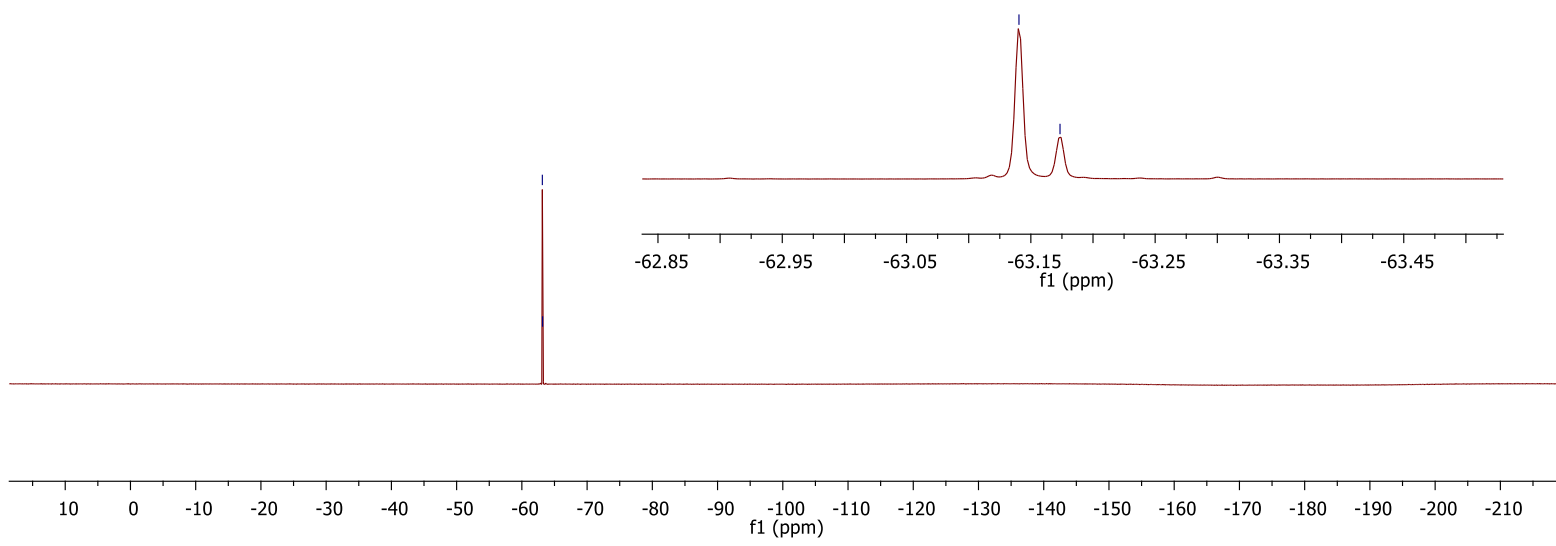

Figure S29: ${ }^{1} \mathrm{H}(400 \mathrm{MHz}),{ }^{13} \mathrm{C}\left\{{ }^{1} \mathrm{H}\right\}(101 \mathrm{MHz})$ and ${ }^{19} \mathrm{~F}\left\{{ }^{1} \mathrm{H}\right\}(376 \mathrm{MHz})$ NMR spectra of $6 \mathrm{i}$ in $\mathrm{CDCl}$. 


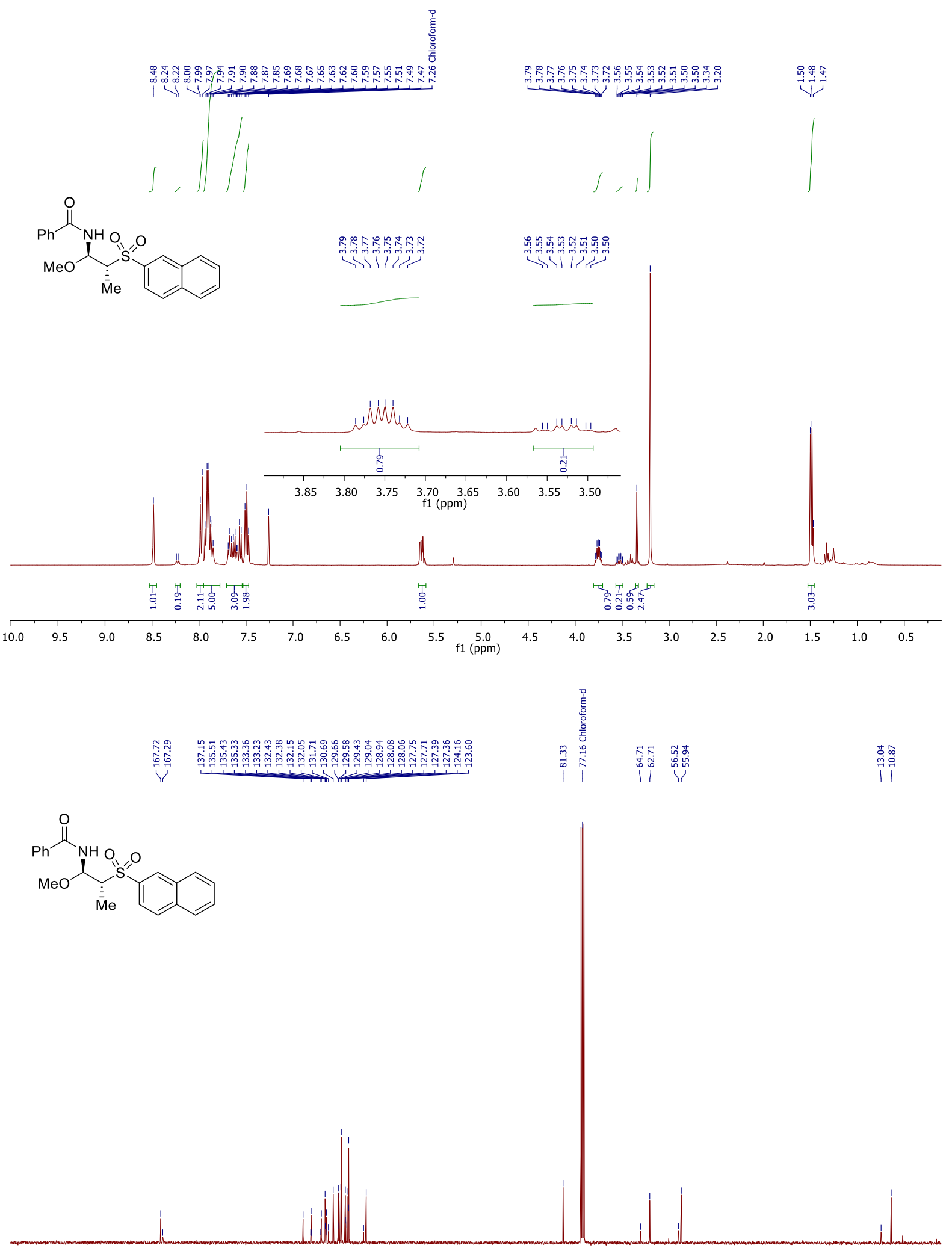

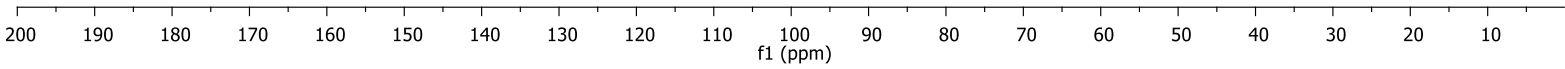

Figure S30: ${ }^{1} \mathrm{H}(400 \mathrm{MHz})$ and ${ }^{13} \mathrm{C}\left\{{ }^{1} \mathrm{H}\right\}(101 \mathrm{MHz}) \mathrm{NMR}$ spectra of $6 \mathrm{j}$ in $\mathrm{CDCl}_{3}$. 

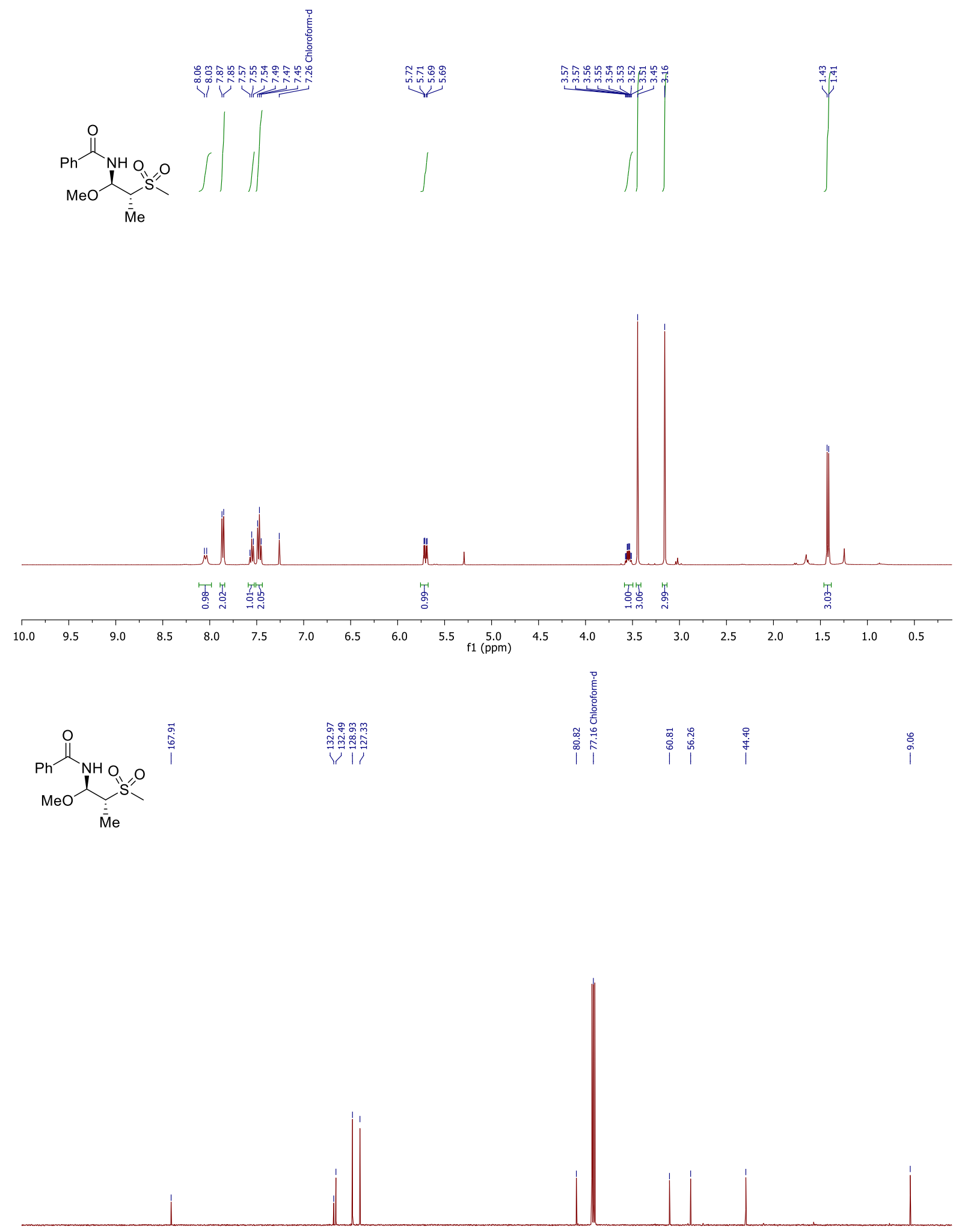

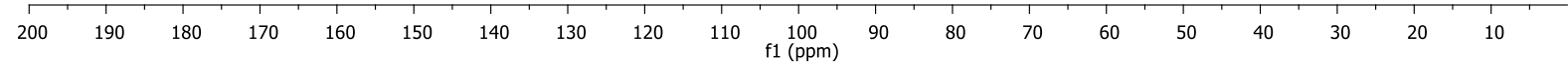

Figure S31: ${ }^{1} \mathrm{H}(400 \mathrm{MHz})$ and ${ }^{13} \mathrm{C}\left\{{ }^{1} \mathrm{H}\right\}(101 \mathrm{MHz}) \mathrm{NMR}$ spectra of $6 \boldsymbol{k}$ in $\mathrm{CDCl}$. 

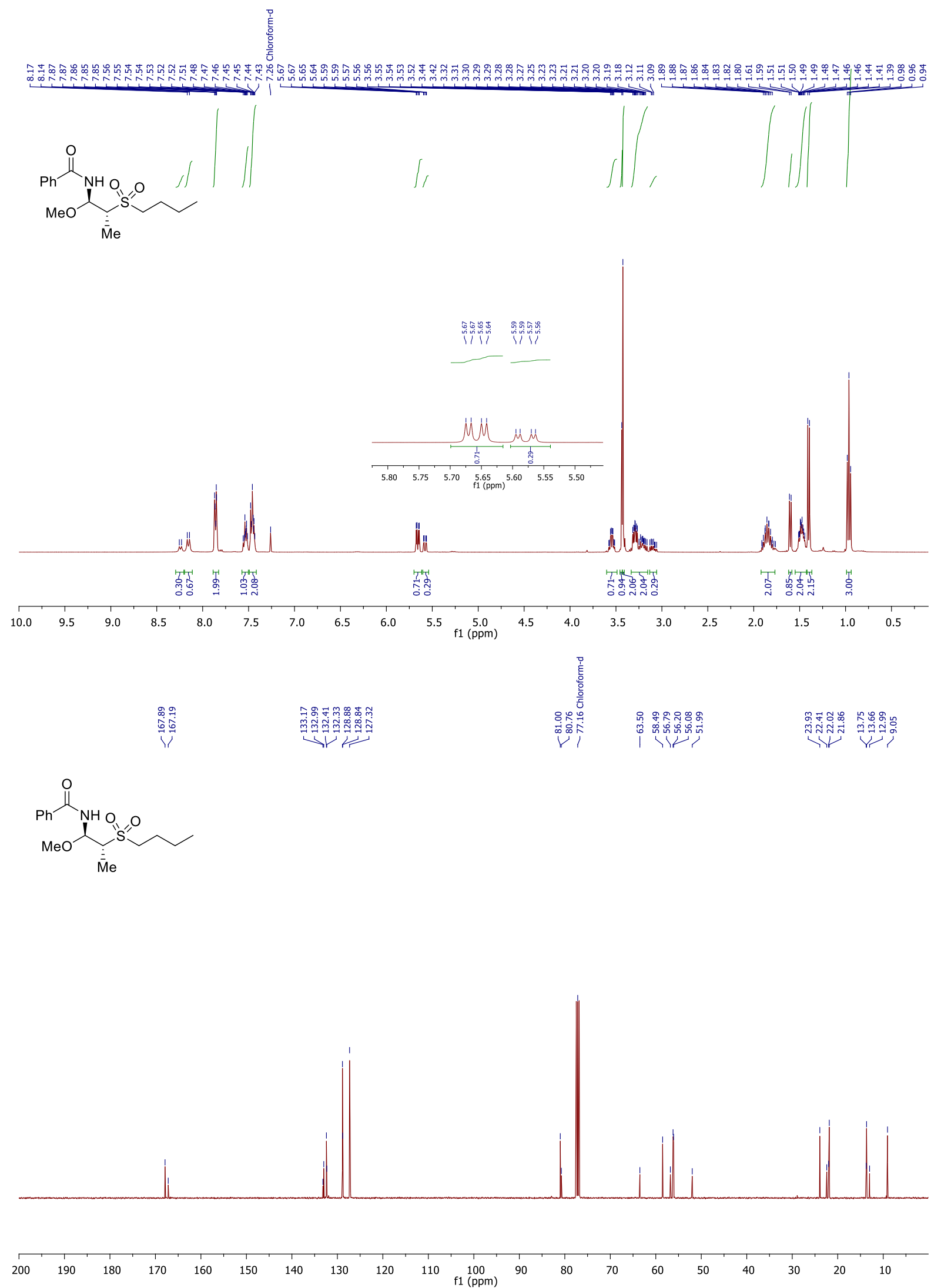

Figure S32: ${ }^{1} \mathrm{H}(400 \mathrm{MHz})$ and ${ }^{13} \mathrm{C}\left\{{ }^{1} \mathrm{H}\right\}(101 \mathrm{MHz}) \mathrm{NMR}$ spectra of $6 \mathrm{In} \mathrm{CDCl}_{3}$. 

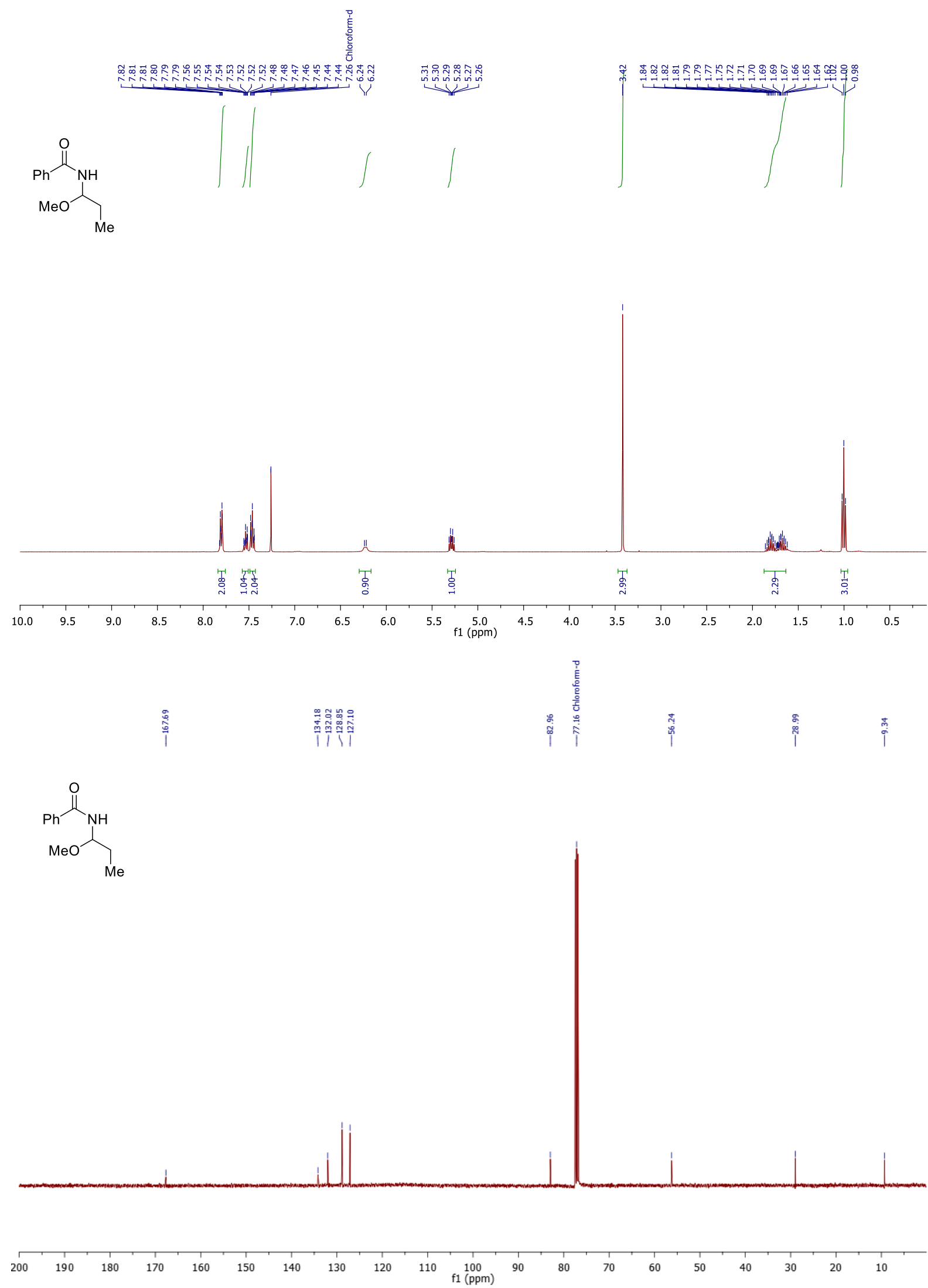

Figure S33: ${ }^{1} \mathrm{H}(400 \mathrm{MHz})$ and ${ }^{13} \mathrm{C}\left\{{ }^{1} \mathrm{H}\right\}(101 \mathrm{MHz}) \mathrm{NMR}$ spectra of 7 in $\mathrm{CDCl}$. 


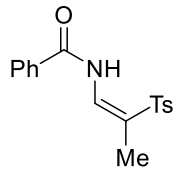

ìj

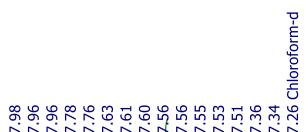

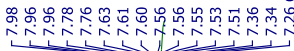
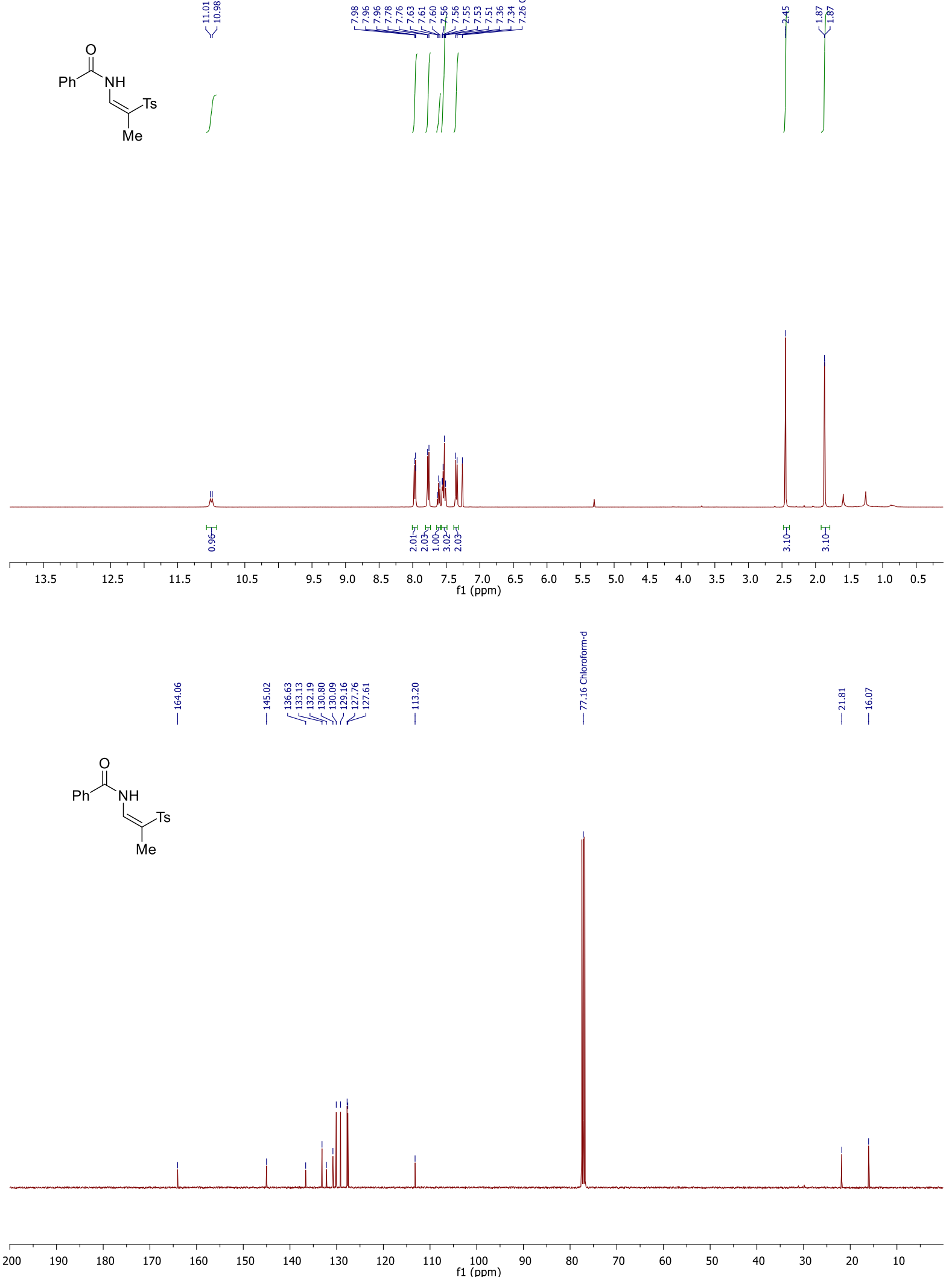

Figure S34: ${ }^{1} \mathrm{H}(400 \mathrm{MHz})$ and ${ }^{13} \mathrm{C}\left\{{ }^{1} \mathrm{H}\right\}(101 \mathrm{MHz}) \mathrm{NMR}$ spectra of 3-(Z) in $\mathrm{CDCl} 3$. 

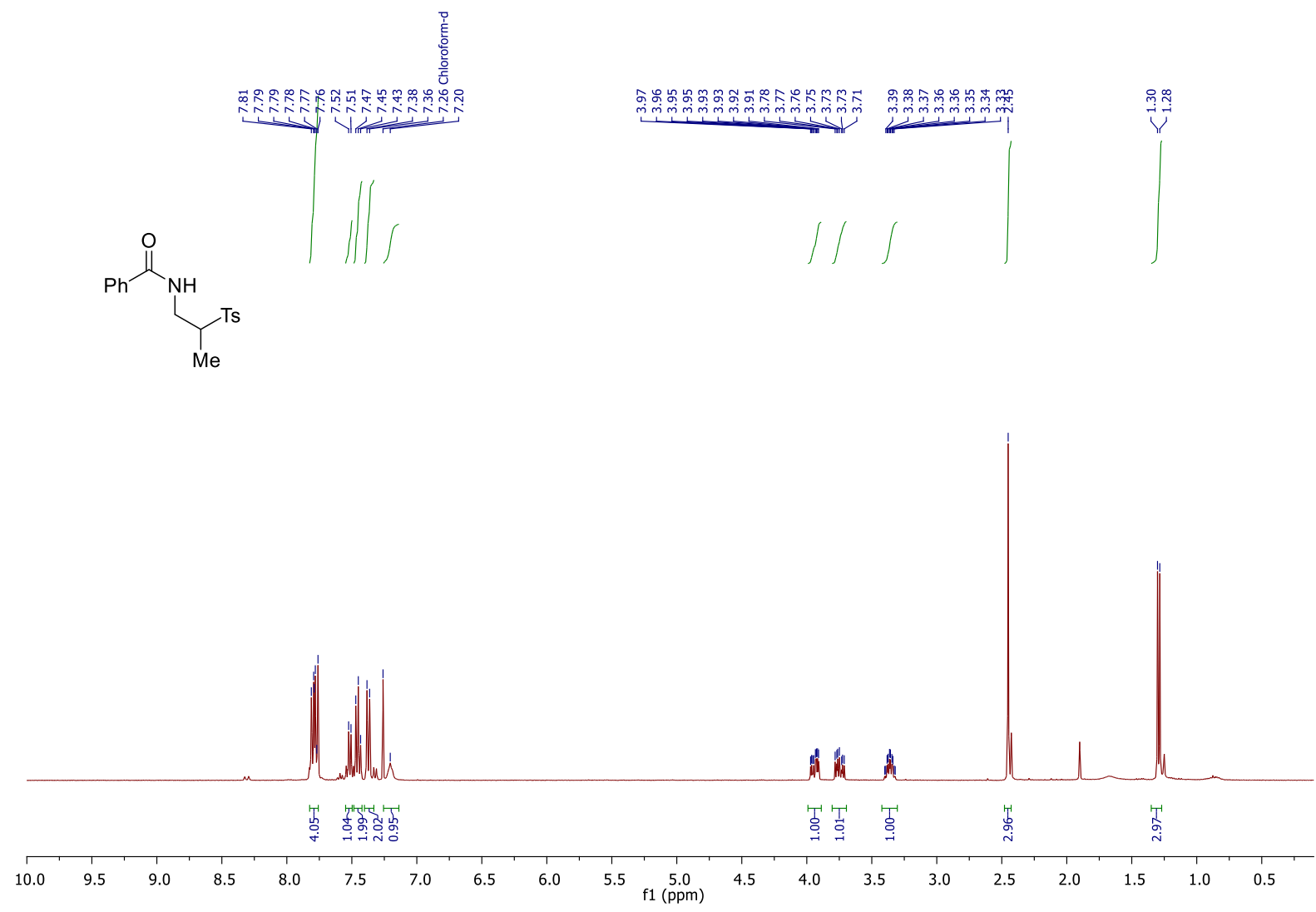

Figure S35: ${ }^{1} \mathrm{H}(400 \mathrm{MHz})$ of 12 in $\mathrm{CDCl}_{3}$. 


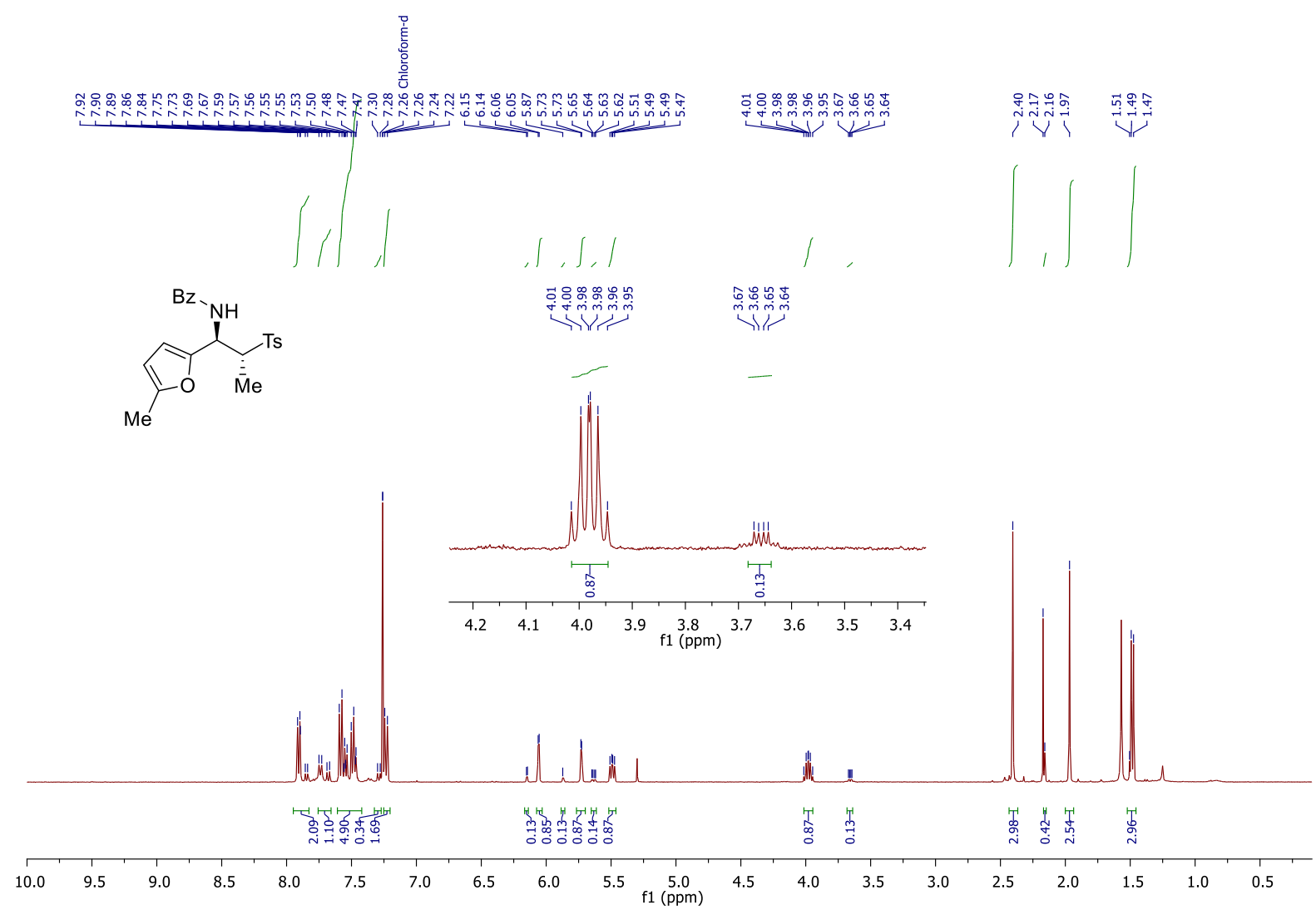

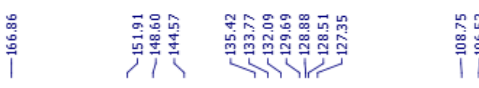

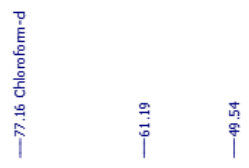

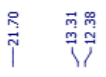

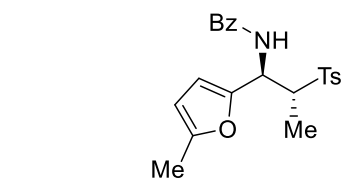

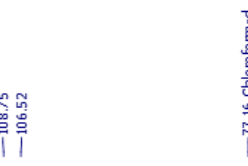
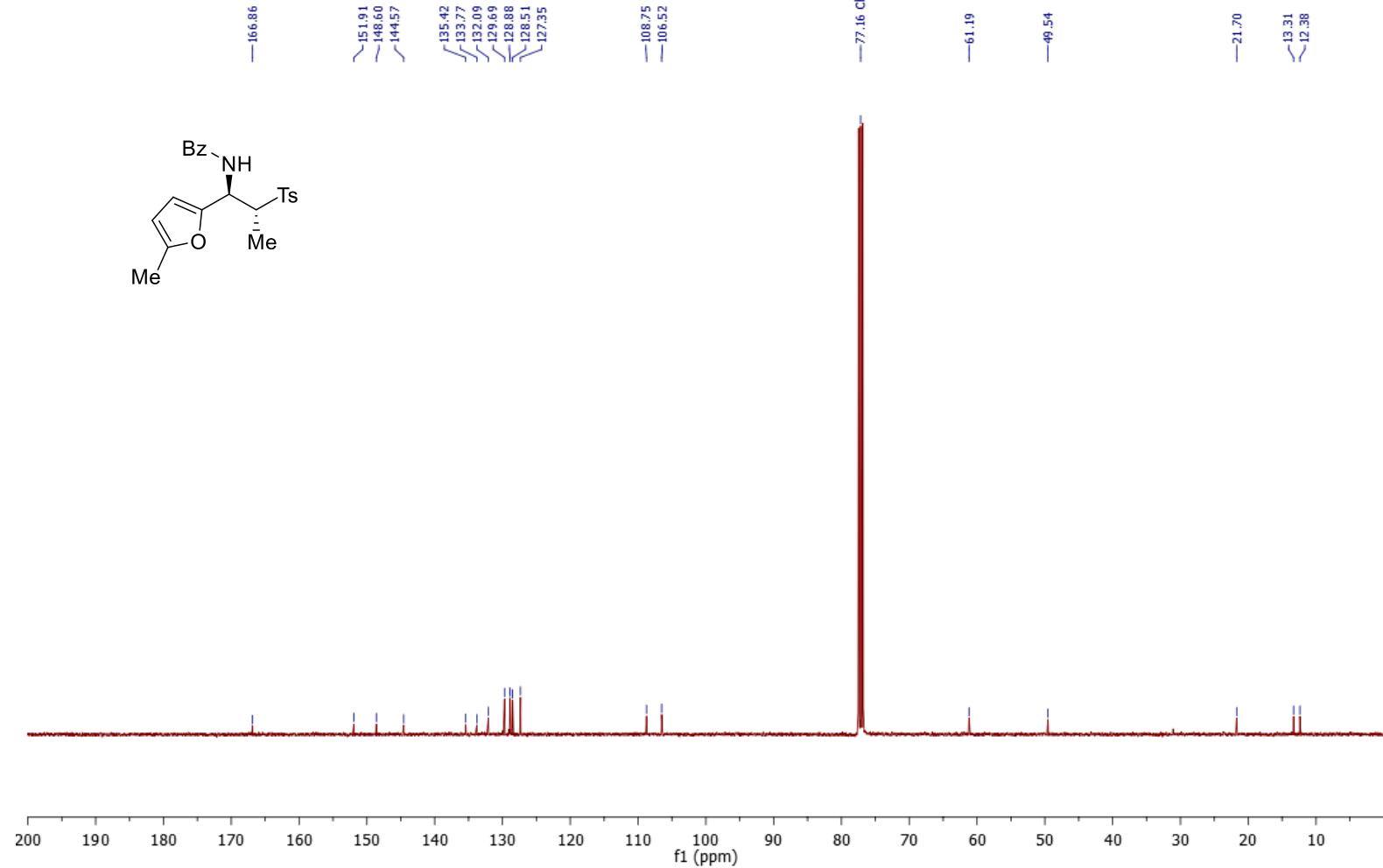

Figure S36: ${ }^{1} \mathrm{H}(400 \mathrm{MHz})$ and ${ }^{13} \mathrm{C}\left\{{ }^{1} \mathrm{H}\right\}(101 \mathrm{MHz}) \mathrm{NMR}$ spectra of $13 \boldsymbol{a}$ in $\mathrm{CDCl}$. 

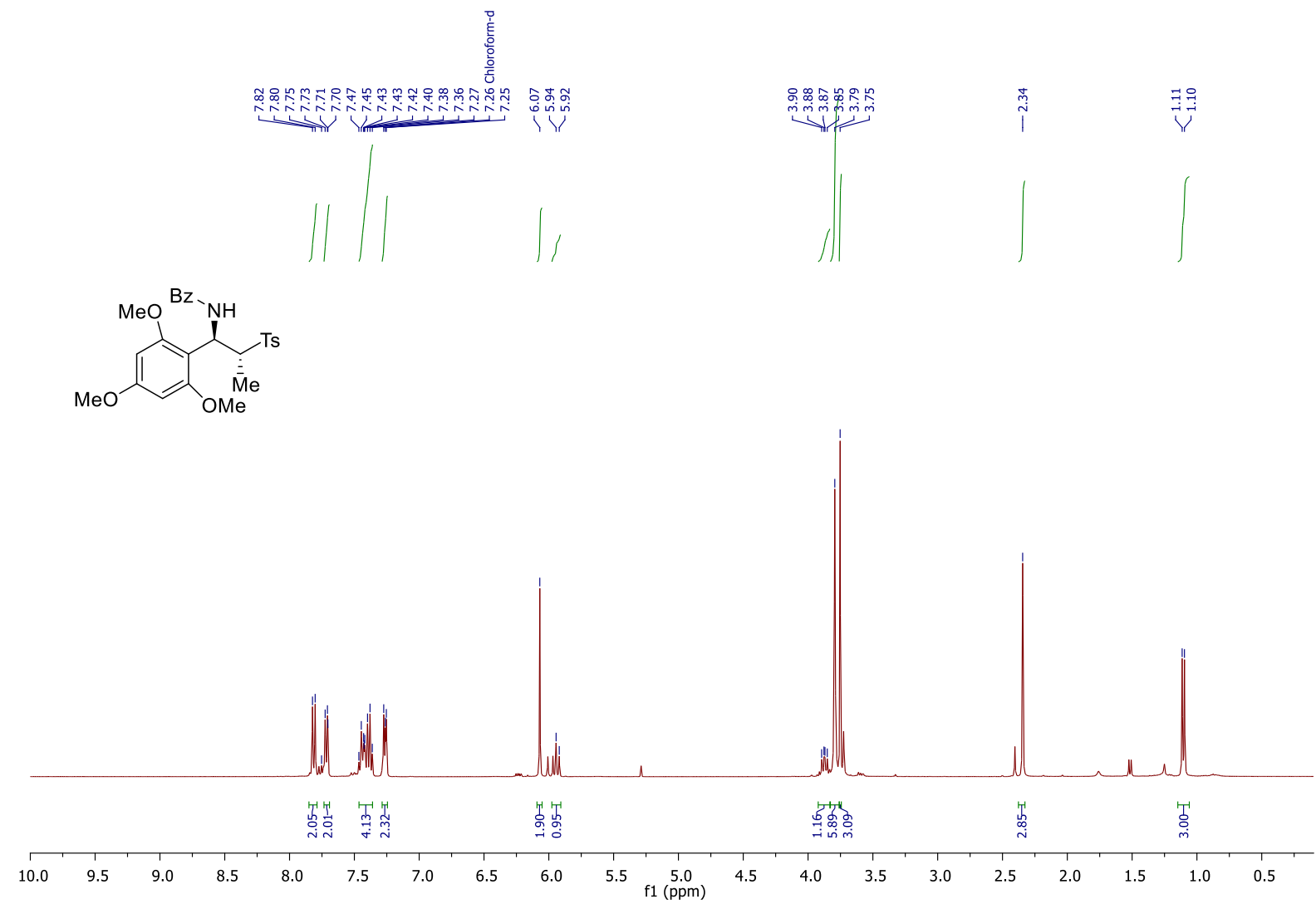

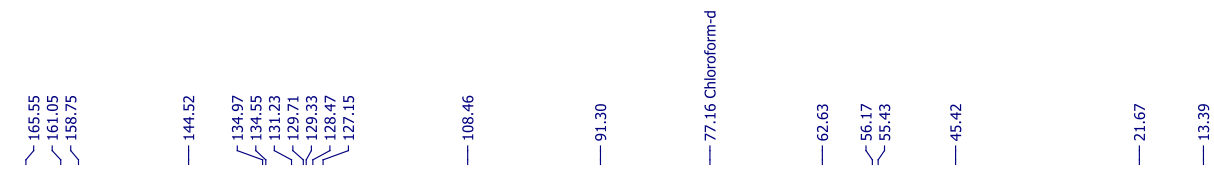
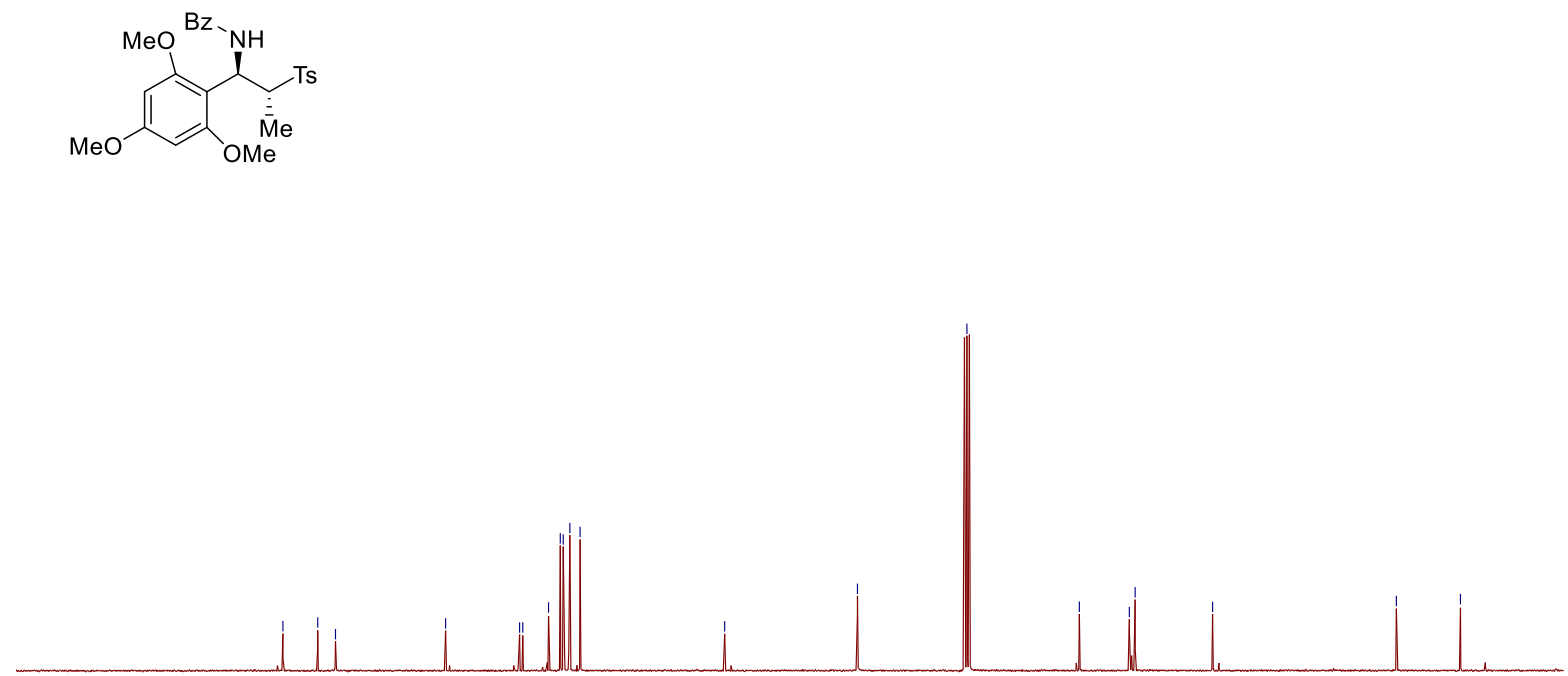

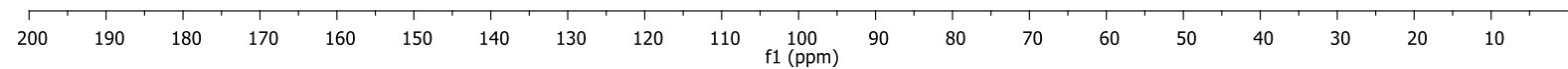

Figure S37: ${ }^{1} \mathrm{H}(400 \mathrm{MHz})$ and ${ }^{13} \mathrm{C}\left\{{ }^{1} \mathrm{H}\right\}(101 \mathrm{MHz}) \mathrm{NMR}$ spectra of $13 \mathrm{~b}$ in $\mathrm{CDCl}$. 

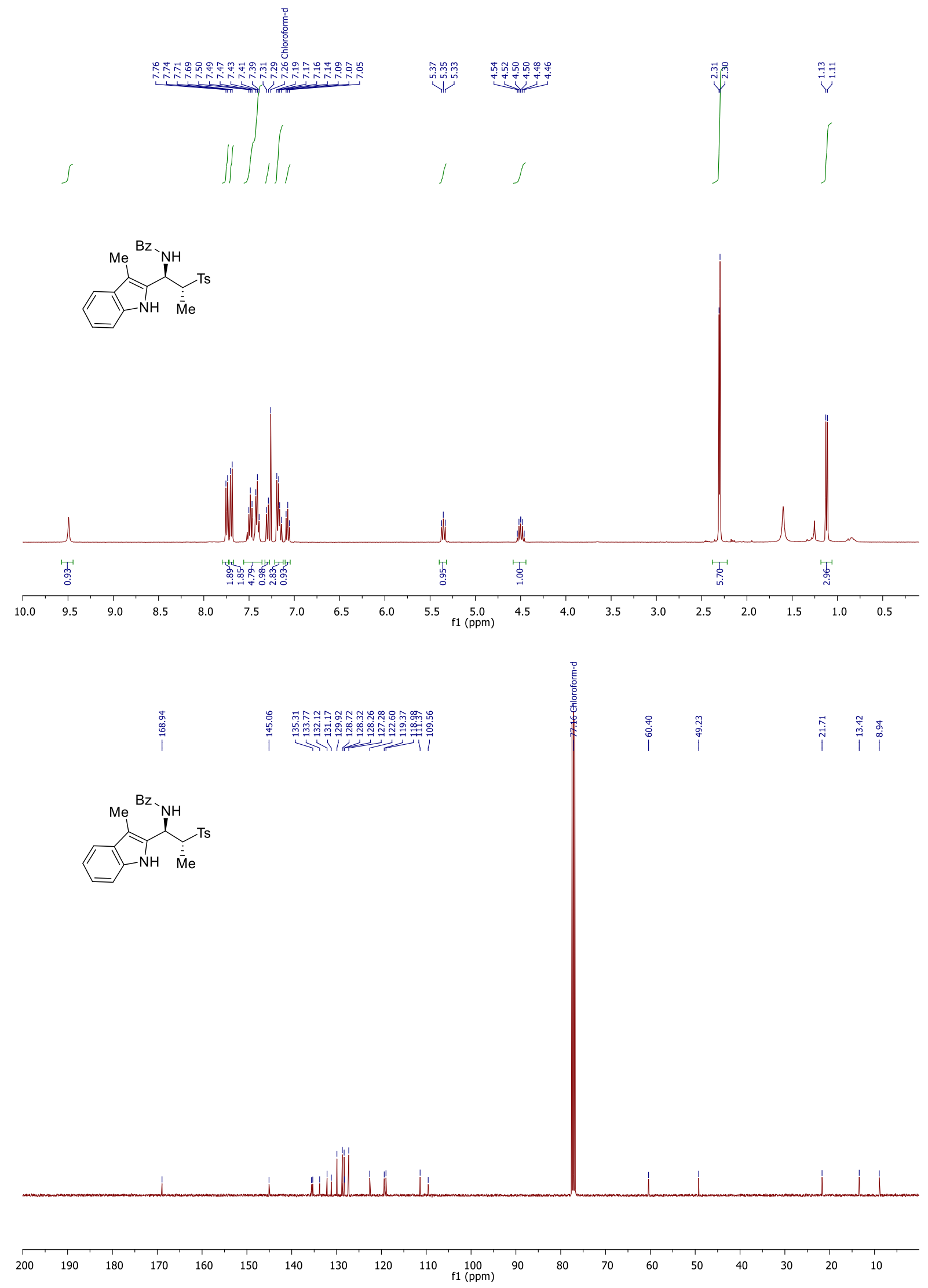

Figure S38: ${ }^{1} \mathrm{H}(400 \mathrm{MHz})$ and ${ }^{13} \mathrm{C}\left\{{ }^{1} \mathrm{H}\right\}(101 \mathrm{MHz}) \mathrm{NMR}$ spectra of $13 \mathrm{c}$ in $\mathrm{CDCl}$. 

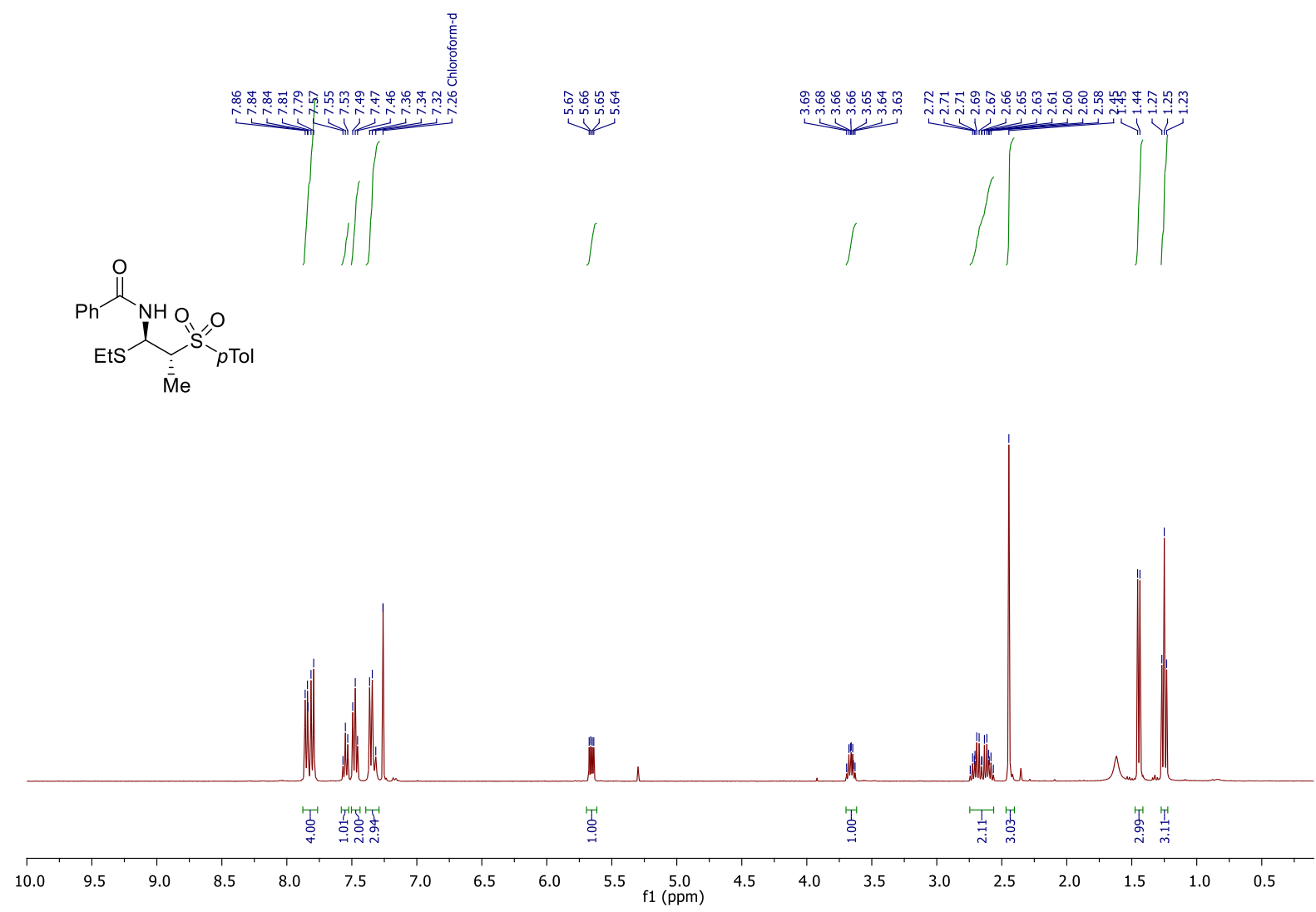

l l
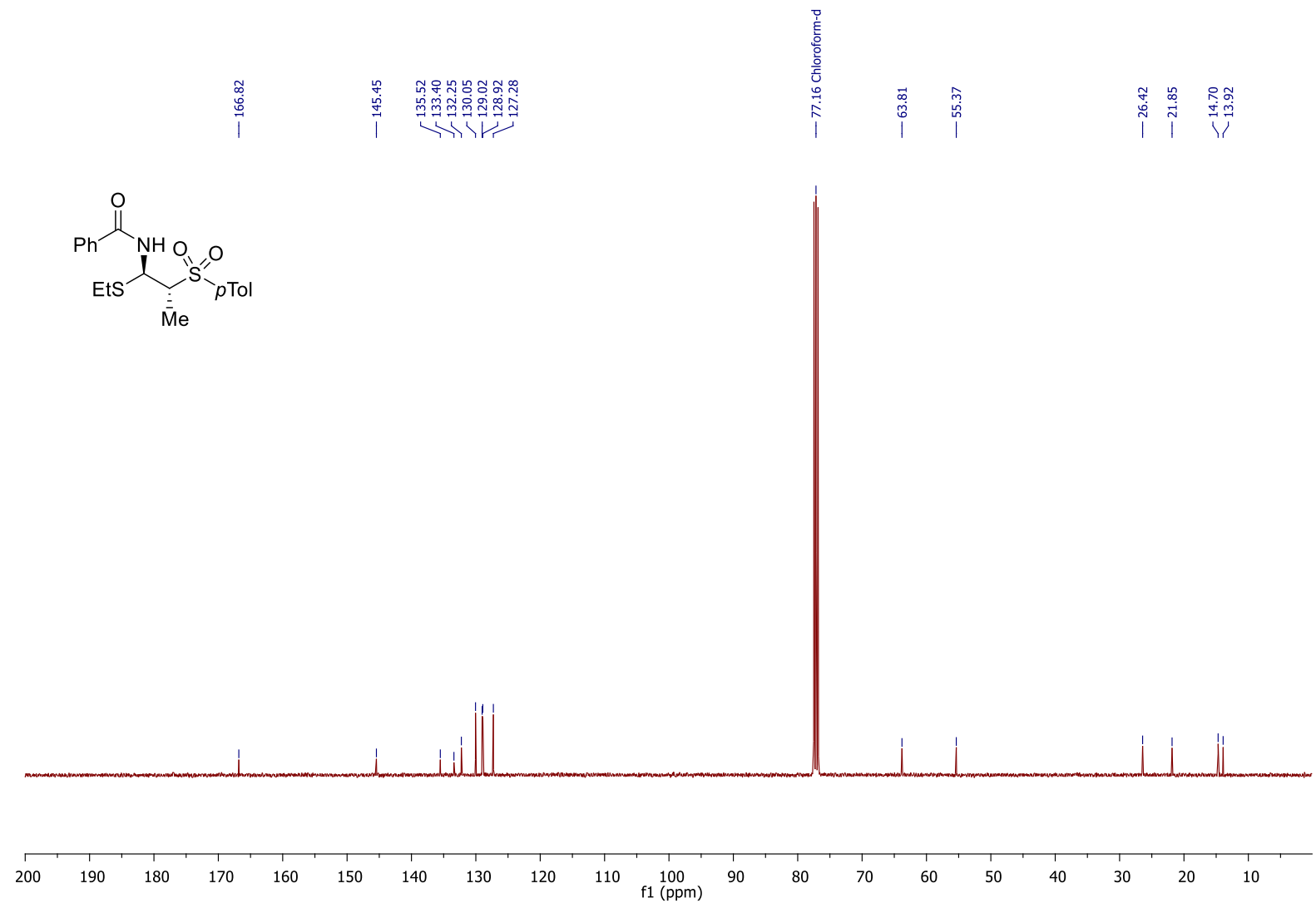

Figure S39: ${ }^{1} \mathrm{H}(400 \mathrm{MHz})$ and ${ }^{13} \mathrm{C}\left\{{ }^{1} \mathrm{H}\right\}(101 \mathrm{MHz}) \mathrm{NMR}$ spectra of $13 d$ in $\mathrm{CDCl}$. 


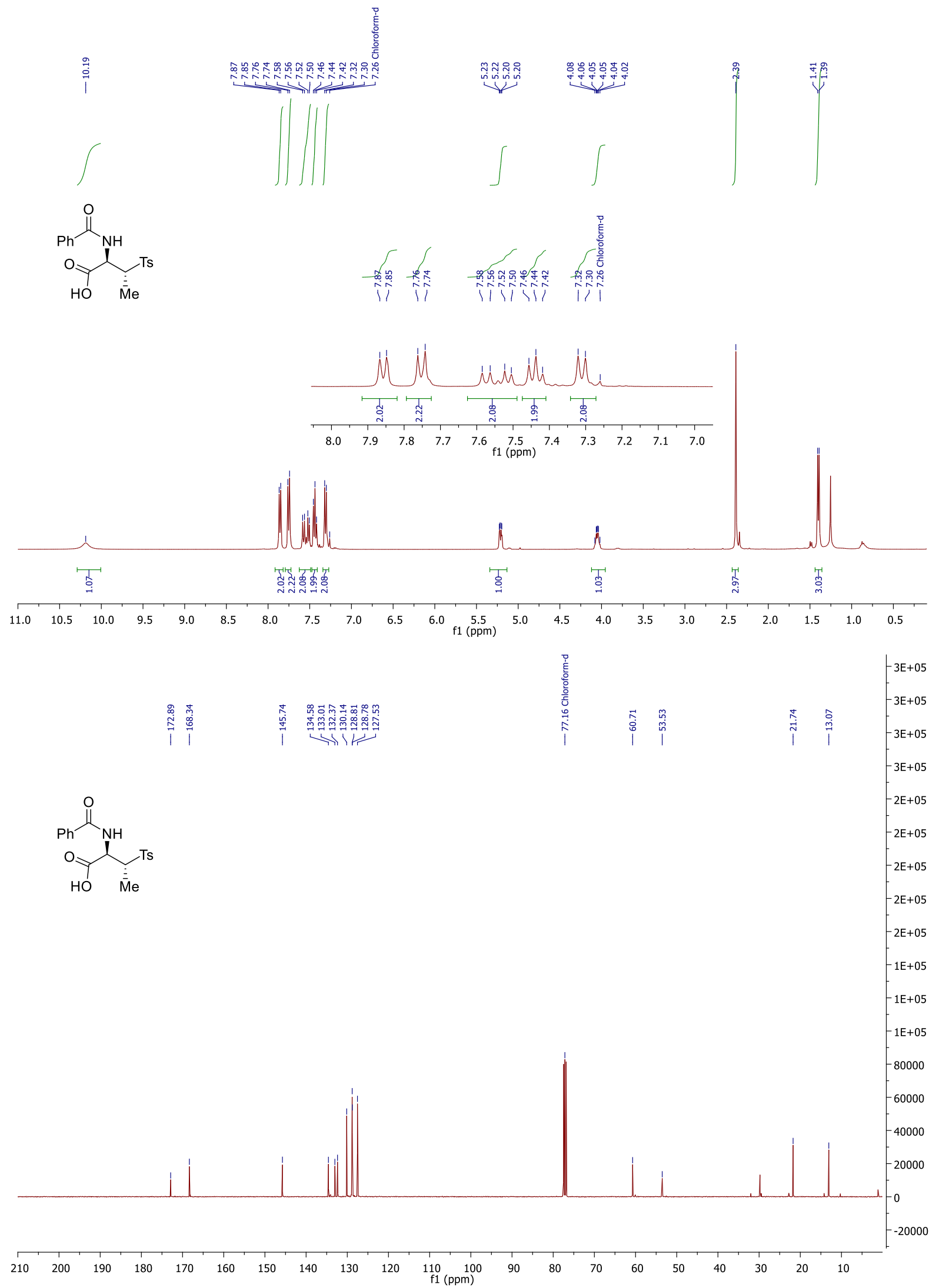

Figure S40: ${ }^{1} \mathrm{H}(400 \mathrm{MHz})$ and ${ }^{13} \mathrm{C}\left\{{ }^{1} \mathrm{H}\right\}(101 \mathrm{MHz})$ NMR spectra of 14 in $\mathrm{CDCl}_{3}$. 


\section{Crystal structure determination}

Crystals suitable for X-Ray of $\mathbf{4 a}$ and $\mathbf{1 3 b}$ could be obtained by slow evaporation from toluene:c-Hex (1:8) and of $(E)-3$ by slow evaporation from ethylacetate.

Data for 3-Z, 4a and 13b (CCDC 1961011, 1961012 and 1967186) were collected at 150.0(1) K on a Rigaku/Oxford diffraction Xcalibur/Gemini dual wavelength diffractometer with a $\mathrm{Cu}-\mathrm{K} \alpha(\lambda=1.54184 \AA)$ radiation X-ray source. Program CrysAlisPro5 (CrysalisPro 2015, Rigaku OD, version 1.171.38.41.) was used for the data collection and reduction. The structures were solved by direct methods using the program SHELXS (SHELXS-2014/78) and refined by full-matrix least squares on F2 using SHELXL-2014/78 program.

All the hydrogen atoms were refined using riding models. 


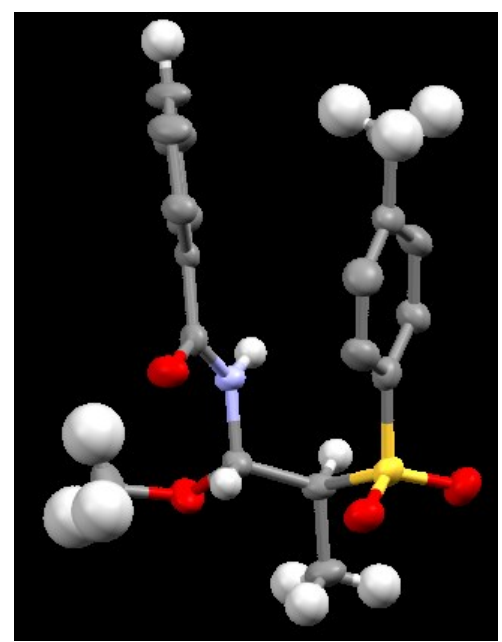

Table S1. Crystal data and structure refinement for 4a. Displacement ellipsoids are drawn at the 50\% probability level.

Empirical formula

Formula weight

Temperature

Wavelength

Crystal system

Space group

Unit cell dimensions

Volume

$\mathrm{Z}$

Density (calculated)

Absorption coefficient

$\mathrm{F}(000)$

Crystal size

Theta range for data collection

Index ranges

Reflections collected

Independent reflections

Completeness to theta $=62.579^{\circ}$

Absorption correction

Max. and min. transmission

Refinement method

Data / restraints / parameters

Goodness-of-fit on $\mathrm{F}^{2}$

Final $\mathrm{R}$ indices [I $>2 \operatorname{sigma}(\mathrm{I})]$

$\mathrm{R}$ indices (all data)

Largest diff. peak and hole
$\mathrm{C}_{18} \mathrm{H}_{21} \mathrm{~N} \mathrm{O}_{4} \mathrm{~S}$

347.42

150(2) K

$1.54184 \AA$

Orthorhombic

$\mathrm{PCa}_{1}$

$\mathrm{a}=22.7230(4) \AA$

$\alpha=90^{\circ}$.

$\mathrm{b}=9.9980(2) \AA$

$\beta=90^{\circ}$.

$\mathrm{c}=15.8190(5) \AA$

$\gamma=90^{\circ}$

3593.83(15) $\AA^{3}$

8

$1.284 \mathrm{Mg} / \mathrm{m}^{3}$

$1.779 \mathrm{~mm}^{-1}$

1472

$0.510 \times 0.060 \times 0.040 \mathrm{~mm}^{3}$

3.891 to $62.579^{\circ}$.

$-26<=\mathrm{h}<=25,-11<=\mathrm{k}<=11,-18<=\mathrm{l}<=18$

16661

$5350[\mathrm{R}(\mathrm{int})=0.0304]$

$100.0 \%$

Semi-empirical from equivalents

1.00000 and 0.69599

Full-matrix least-squares on $\mathrm{F}^{2}$

$5350 / 1 / 440$

1.106

$\mathrm{R} 1=0.0518, \mathrm{wR} 2=0.1388$

$\mathrm{R} 1=0.0554, \mathrm{wR} 2=0.1425$

0.661 and -0.247 e. $\AA^{-3}$ 


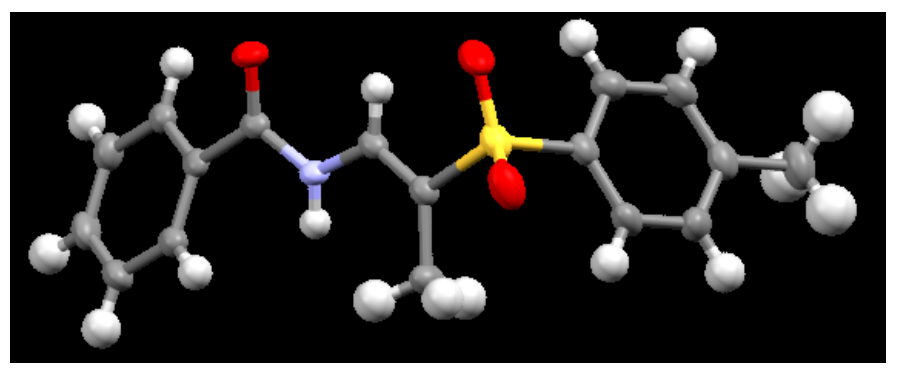

Table S2. Crystal data and structure refinement for 3-(E). Displacement ellipsoids are drawn at the $50 \%$ probability level.

Empirical formula

Formula weight

Temperature

Wavelength

Crystal system

Space group

Unit cell dimensions

Volume

Z

Density (calculated)

Absorption coefficient

$\mathrm{F}(000)$

Crystal colour and habit

Crystal size

Theta range for data collection

Index ranges

Reflections collected

Independent reflections

Completeness to theta $=62.746^{\circ}$

Absorption correction

Max. and min. transmission

Refinement method

Data / restraints / parameters

Goodness-of-fit on $\mathrm{F}^{2}$

Final R indices [I $>2$ sigma(I)]

$\mathrm{R}$ indices (all data)

Largest diff. peak and hole
$\mathrm{C}_{17} \mathrm{H}_{17} \mathrm{NO}_{3} \mathrm{~S}$

315.37

$150(2) \mathrm{K}$

$1.54184 \AA$

Orthorhombic

$\mathrm{Pbca}$

$\mathrm{a}=10.7452(1) \AA$

$\alpha=90^{\circ}$.

$\mathrm{b}=8.6766(1) \AA$

$\beta=90^{\circ}$.

$\mathrm{c}=34.0401(3) \AA$

$3173.62(5) \AA^{3}$

8

$1.320 \mathrm{Mg} / \mathrm{m}^{3}$

$1.914 \mathrm{~mm}^{-1}$

1328

Colorless needle

$0.359 \times 0.147 \times 0.135 \mathrm{~mm}^{3}$

4.867 to $62.746^{\circ}$.

$-12<=\mathrm{h}<=12,-9<=\mathrm{k}<=8,-38<=\mathrm{l}<=39$

21796

$2527[\mathrm{R}(\mathrm{int})=0.0235]$

$99.6 \%$

Semi-empirical from equivalents

1.00000 and 0.76945

Full-matrix least-squares on $\mathrm{F}^{2}$

$2527 / 0 / 201$

1.070

$\mathrm{R} 1=0.0314, \mathrm{wR} 2=0.0769$

$\mathrm{R} 1=0.0321, \mathrm{wR} 2=0.0775$

0.223 and -0.371 e. $\AA^{-3}$ 


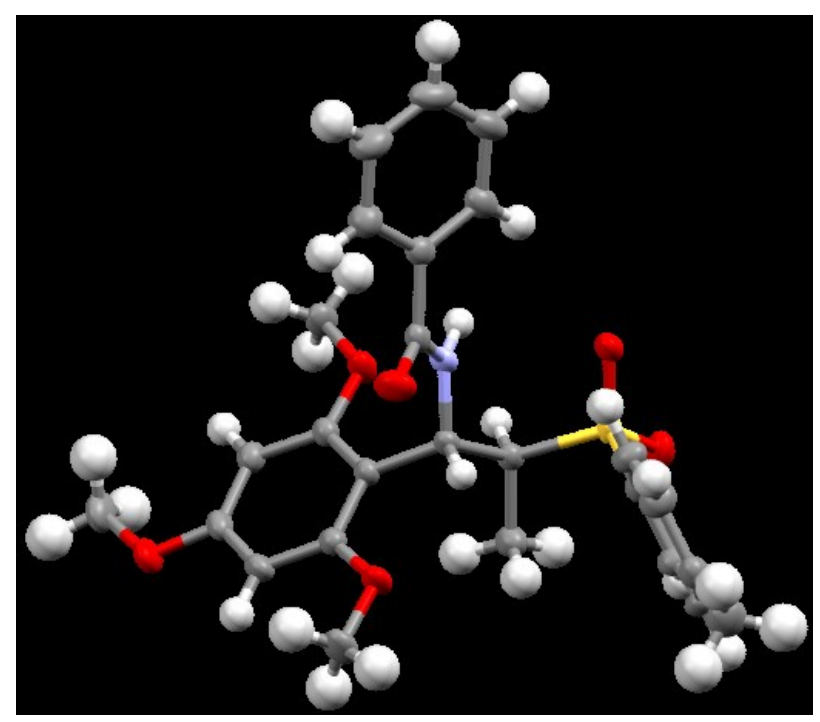

Table S3. Crystal data and structure refinement for 13b. Displacement ellipsoids are drawn at the $50 \%$ probability level.

Empirical formula

Formula weight

Temperature

Wavelength

Crystal system

Space group

Unit cell dimensions

Volume

Z

Density (calculated)

Absorption coefficient

$\mathrm{F}(000)$

Crystal size

Theta range for data collection

Index ranges

Reflections collected

Independent reflections

Completeness to theta $=62.727^{\circ}$

Absorption correction

Max. and min. transmission

Refinement method

Data / restraints / parameters

Goodness-of-fit on $\mathrm{F}^{2}$

Final R indices [I $>2 \operatorname{sigma}(\mathrm{I})]$

$\mathrm{R}$ indices (all data)

Largest diff. peak and hole

\section{$\mathrm{C}_{26} \mathrm{H}_{29} \mathrm{NO}_{6} \mathrm{~S}$}

483.56

$150(2) \mathrm{K}$

$1.54184 \AA$

Monoclinic

$P 21 / n$

$\mathrm{a}=9.3967(2) \AA$

$\alpha=90^{\circ}$.

$\mathrm{b}=14.1104(2) \AA$

$\beta=94.481(2)^{\circ}$.

$\mathrm{c}=18.2896(4) \AA$

$\gamma=90^{\circ}$.

2417.63(8) $\AA^{3}$

4

$1.329 \mathrm{Mg} / \mathrm{m}^{3}$

$1.543 \mathrm{~mm}^{-1}$

1024

$0.230 \times 0.180 \times 0.060 \mathrm{~mm}^{3}$

3.961 to $62.727^{\circ}$.

$-10<=\mathrm{h}<=10,-16<=\mathrm{k}<=13,-20<=\mathrm{l}<=21$

10792

$3871[\mathrm{R}(\mathrm{int})=0.0243]$

$99.7 \%$

Analytical

0.911 and 0.736

Full-matrix least-squares on $\mathrm{F}^{2}$

3871 / 0 / 312

1.061

$\mathrm{R} 1=0.0339, \mathrm{wR} 2=0.0923$

$\mathrm{R} 1=0.0373, \mathrm{wR} 2=0.0940$

0.319 and -0.391 e. $\AA^{-3}$ 